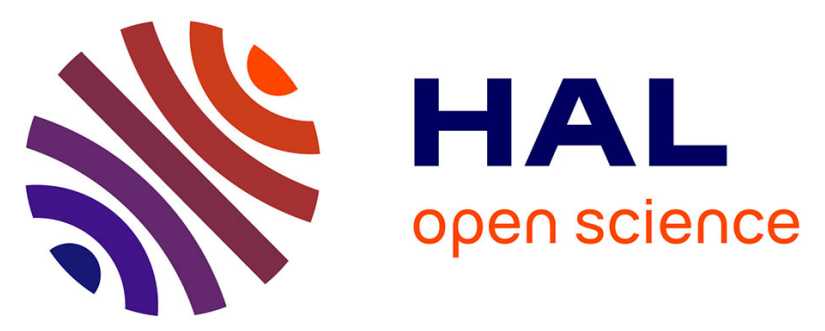

\title{
Twenty years of groundwater evolution in the Triassic sandstone aquifer of Lorraine: Impacts on baseline water quality
}

\author{
Hélène Celle-Jeanton, Frederic Huneau, Yves Travi, W. M. Edmunds
}

\section{- To cite this version:}

Hélène Celle-Jeanton, Frederic Huneau, Yves Travi, W. M. Edmunds. Twenty years of groundwater evolution in the Triassic sandstone aquifer of Lorraine: Impacts on baseline water quality. Applied Geochemistry, 2009, 24 (7), pp.1198-1213. 10.1016/j.apgeochem.2009.03.005 . hal-00453278

\author{
HAL Id: hal-00453278 \\ https://hal.science/hal-00453278
}

Submitted on 29 Nov 2019

HAL is a multi-disciplinary open access archive for the deposit and dissemination of scientific research documents, whether they are published or not. The documents may come from teaching and research institutions in France or abroad, or from public or private research centers.
L'archive ouverte pluridisciplinaire $\mathbf{H A L}$, est destinée au dépôt et à la diffusion de documents scientifiques de niveau recherche, publiés ou non, émanant des établissements d'enseignement et de recherche français ou étrangers, des laboratoires publics ou privés. 


\title{
Twenty years of groundwater evolution in the Triassic sandstone aquifer of Lorraine: Impacts on baseline water quality
}

\author{
Hélène Celle-Jeanton ${ }^{\mathrm{a}}$, Frédéric Huneau ${ }^{\mathrm{b}, *}$, Yves Travi $^{\mathrm{c}}$, W.M. Edmunds ${ }^{\mathrm{d}}$ \\ ${ }^{a}$ University of Clermont-Ferrand, LMV CNRS UMR 6524, 5 rue Kessler, 63038 Clermont-Ferrand, France \\ ${ }^{\mathrm{b}}$ University of Bordeaux, GHYMAC Géosciences Hydrosciences, Faculty of Earth and Marine Sciences, B18 avenue des Facultés, 33405 Talence, France \\ ${ }^{\mathrm{c}}$ University of Avignon, Department of Hydrogeology, UMR 1114 INRA-UAPV, Faculty of Sciences, 33 rue Louis Pasteur, 84000 Avignon, France \\ ${ }^{\mathrm{d}}$ University of Oxford, Centre for the Environment, South Park Road, Oxford OX1 3QY, UK
}

The Lorraine Triassic Sandstone Aquifer (LTSA), which has already been the subject of a chemical and radioisotopic study (1979), is used to investigate the impacts of 20 a of large scale pumping on baseline water quality. In parallel, new sampling of the aquifer (2001) provides new inorganic geochemical data (including trace elements) that allow improving the knowledge of baseline conditions and hydrochemical functioning of a major sandstone aquifer. The good correlation between ${ }^{14} \mathrm{C}$ activities, temperature and depth along the main flow line indicate regular downgradient trends and possible water stratification. Unreactive tracers, mainly stable isotope ratios ${ }^{18} \mathrm{O}$ and ${ }^{2} \mathrm{H}$, as well as $\mathrm{C}$ isotopes are used to define a timescale for the aquifer, showing two groups of groundwater, namely of modern and Holocene age, and late Pleistocene age, with a mixing zone. Baseline quality is then represented by a wide range of concentrations, mainly the result of time-dependent water-rock interaction, as already observed elsewhere in Triassic sandstone aquifers. Some trace elements such as $\mathrm{Li}, \mathrm{Rb}, \mathrm{Cs}$, which are not limited by solubility constraints, show linear trends. During saturated flow downgradient, the chemistry is also specifically characterised by a regular increase in $\mathrm{Na}$ and $\mathrm{Cl}$ (and locally $\mathrm{SO}_{4}$ ) as a result of evaporite dissolution related to overlying or basement limits. The aquifer is mostly oxidising with a redox boundary marked by $\mathrm{U}$ decrease, some $40 \mathrm{~km}$ from outcrop.

Groundwater abstraction since the 1970s has created a strong lowering (10-150 m) of the water table, especially from 1970 to 1980 . Based on nine boreholes, previously sampled in 1979, a decreasing evolution in radiocarbon content of the TDIC, together with significant evolution of ${ }^{18} \mathrm{O}$ content, indicate that old groundwater has moved upgradient. The major difference in terms of baseline evolution is observed using $\mathrm{Cl}$ and $\mathrm{Na}$ concentration and, locally, $\mathrm{SO}_{4}$, indicating an increasing influence of water circulation involving overlying or basement formations, or of mixing with Permian waters. From the point of view of aquifer management, the perceptible $\mathrm{NO}_{3}$ increase could provide information on the progress of any contamination under the aerobic conditions. In addition, the few key elements, indicators of disequilibrium, related to overlying or deep waters, should be included in regular monitoring programmes.

\section{Introduction}

Understanding the natural baseline quality of groundwaters requires knowledge of the aquifer mineralogy, flow paths, residence time and geochemical controls (Edmunds and Shand, 2008). Baseline geochemistry is an essential prerequisite for understanding pollution, for identifying over-exploitation and for imposing regulatory limits, as suggested in the European Water Framework Directive 2000/60/EC. However, groundwater exploitation, by means of drilling, may penetrate water of different ages and/or quality with increasing depth and then disturb hydrogeological conditions. The younger waters may include some anthropogenic

\footnotetext{
* Corresponding author. Tel.: +33 5400088 41; fax: +33 540003113 .

E-mail address: f.huneau@ghymac.u-bordeaux1.fr (F. Huneau).
}

component affecting water quality and can thus badly influence deeper parts of the aquifer.

Investigations using a combination of geochemical and isotopic methods were carried out on the Lorraine Triassic Sandstone Aquifer (LTSA) in 1979 (Blavoux and Olive, 1981) and interpreted in terms of residence time of groundwater within the aquifer. Another study carried out by Marty et al. (2003) focused on the isolating properties of aquitards. As part of studies of representative European aquifers - BaSeLiNe (Edmunds and Shand, 2008) completed under the European Union Framework VI programme, the LTSA was selected for a comparison of modern analysis with those carried out 20 a previously. The red-bed sandstones of the Lorraine aquifer are also typical of similar aquifers in Europe used for water supply (in the UK and Germany as well as France). These aquifers are also of importance in many other regions, in North Africa and 
the Middle East as well as North America (Lloyd and Pim, 1990; Edmunds et al., 2003; Gossel et al., 2004; Nastiv et al., 2008). A similar study was carried out for the East Midlands Triassic aquifer (UK) and the present paper compares the groundwater chemistry of these two aquifers. Both are characterised by groundwaters of similar age and have large sections of aerobic groundwaters which persist, due to the absence of any significant amount of organic material. The LTSA aquifer can be viewed as being important for the study of hydrogeological trends (mainly conducted using isotopic studies) as well as defining baseline characteristics within a typical sandstone aquifer.

This paper presents the results obtained from a new field campaign realised in 2001 on the LTSA, in order to highlight the modifications of the water quality in relation to the modifications of the potentiometric levels and the circulation flow path that have occurred after the large scale pumping that has taken place over the 20 a period. In addition, the identification of major groundwater geochemical characteristics and the determination of controlling processes responsible for downgradient changes in water chemistry lead to an improvement of the knowledge of the LTSA baseline and hydrogeological functioning in terms of dynamics of groundwater flow.

\section{Geological and hydrogeological setting}

The LTSA forms an important aquifer on the eastern limb of the Paris Basin, in eastern France. It provides water supply to a number of large towns in the Lorraine region, where it is the most important reservoir. The LTSA is used as a water supply (drinking water and farming and industrial uses), for underground gas storage, for the thermal water industry and geothermal energy production. It has been intensely exploited by large scale pumping which began in the 1970s and created a significant decrease in head level. In the Sarre area groundwater flow is greatly influenced by coal mine exploitation (natural outlet and water pumped out of coal mines). Land use is dominated by farming (arable and livestock), although industrial areas are present around some large towns. The western and northwestern portions of the aquifer suffer from naturallypoor water quality and there is less abstraction than in the more easterly areas. Most of the area is covered by Mesozoic deposits (upper Trias and Lias) with low permeability. The recharge of the LTSA only occurs through the outcropping zones, so the Mesozoic cover provides groundwater with protection from anthropogenic inputs. The current impact could be from diffuse or wide-spread pollution sources from agricultural or industrial activities in the areas of outcrop.

\subsection{Geological features}

In eastern France, the lower Triassic is mainly represented by sandstones and conglomerates which crop out along the western border of the Vosges Mountains. Being $500 \mathrm{~m}$ thick in the outcropping areas, they become gradually deeper lying and thinner towards the centre of the Paris Basin (Fig. 1). The lower Triassic sandstones comprise with decreasing age (Fig. 2): (1) Annweiler sandstones, red or grey-red fine grained quartzitic and feldspathic sandstones up to $60 \mathrm{~m}$ thick that often contain dolomitic nodules and Mn coatings, (2) Vosges sandstones, 300-400 m thick pink sandstones, locally feldspathic, Fe-cemented, with an uppermost conglomerate facies, (3) intermediate layers that alternate between coarse feldspathic sandstones (locally called Main Conglomerate), red or green clay beds and compact dolomites, (4) Voltzia sandstones, fine grained micaceous and feldspathic sandstones up to $20 \mathrm{~m}$ thick that often contain pyrite. These permeable formations are covered by about $600 \mathrm{~m}$ of deposits: (i) succession of shell sandstones, dolomites, marls and calcareous units up to $285 \mathrm{~m}$ thick from the Muschelkalk, (ii) marls and clays that contain evaporitic beds from the Keuper and the lower Lias up to $270 \mathrm{~m}$ thick. Finally, Triassic formations are covered by Dogger deposits, oolitic limestone interbedded with marls. The Triassic usually overlies Permian formations consisting of argillaceous cemented sandstone and volcanic flows. Locally, evaporitic deposits, and particularly halite, have been recognised in the Permian formations (Salado and Passavy, 1980).

During at least the latter half of the Tertiary, the Vosges Massif has been uplifted by Alpine deformation while the central part of the Paris Basin has been affected by subsidence. This deformation is characterised by anticlinal and synclinal folds arranged in the direction of the Variscan orogeny (SW-NE) and is cut by SSENNW major faults.

The aquifer mineralogy is dominated by silica with coatings of carbonated Fe cement (7\% on average; El-Ghali et al., 2009), and locally clay-enriched, mainly illite and some kaolinite (Tournier et al., 1999). Some muscovite can also be found (Surma et al., 2003). Diagenetic feldspar is present in some layers (up to 1\%) as K-feldspar and albite (El-Ghali et al., 2009). The principal conglomerate levels are mainly quartzitic, sometimes covered by fine clayey sandstones including dolomite nodules and local beds of quartz and calcite. The chemical composition of the different kinds of Lorraine sandstones is presented in Table 1.

\subsection{Hydrogeological features}

The LTSA extends from the eastern outcrop zone for about $150 \mathrm{~km}$ westward, where it progressively disappears under Jurassic and Cretaceous cover. South of a line running from Vittel to Epinal, crystalline rocks form the substratum. North of this line sandstones usually overlie Permian formations, with the exception of the Sarre-Lorraine anticline crest where they lie over Carboniferous rocks. The crystalline, Carboniferous rocks act as an aquitard, but local connections can exist between Permian and Triassic groundwater. Moreover, the SSE-NNW faults could play a major hydrogeological role by connecting the LTSA with the overlying Muschelkalk shelly sandstones and Dogger oolitic limestone aquifers. On the whole, confined LTSA water losses by upward leakage towards and through the Muschelkalk/Keuper interface are estimated to be only a few mm/a (Vaute, 2004). In the high pumping areas, where drawdown is important, downward leakage can occur which entails a risk of contamination of pristine waters of the LTSA by highly mineralized waters from the overlying formations. For this reason, LTSA water quality cannot be considered as homogeneous. In addition, it must also be pointed out that the high anisotropy of the reservoir could give rise to natural groundwater quality stratification.

The LTSA represents a huge reservoir thanks to its large extent and thickness and to its well developed permeability of mostly interstitial type. A few compact sandstone layers show, in addition, quite important fracture porosity (Surma et al., 2003). The LTSA area is around $3000 \mathrm{~km}^{2}$ for the unconfined and $25,000 \mathrm{~km}^{2}$ for the confined part from which only $6500 \mathrm{~km}^{2}$ are exploitable, the rest being too heavily mineralized to be used for both drinking and industrial water supplies. The renewal rate was about $0.05 \%$ and the abstraction was estimated at about $110 \mathrm{Mm}^{3} \mathrm{a}^{-1}$ in 2000 . The total volumes of the different kinds of groundwater uses for the year 2000 are summarized in Table 2 . It must be noted that more than $90 \%$ of the volume abstracted comes from the northern part of the LTSA both in France (79\%) and Germany (11.5\%). The first boreholes tapping the LTSA were constructed at the beginning of the 19th century; 30 boreholes were designed in the unconfined and confined LTSA between 1900 and 1930. In the north Lorraine Region, from the 1930s, a series of boreholes were drilled to ensure 


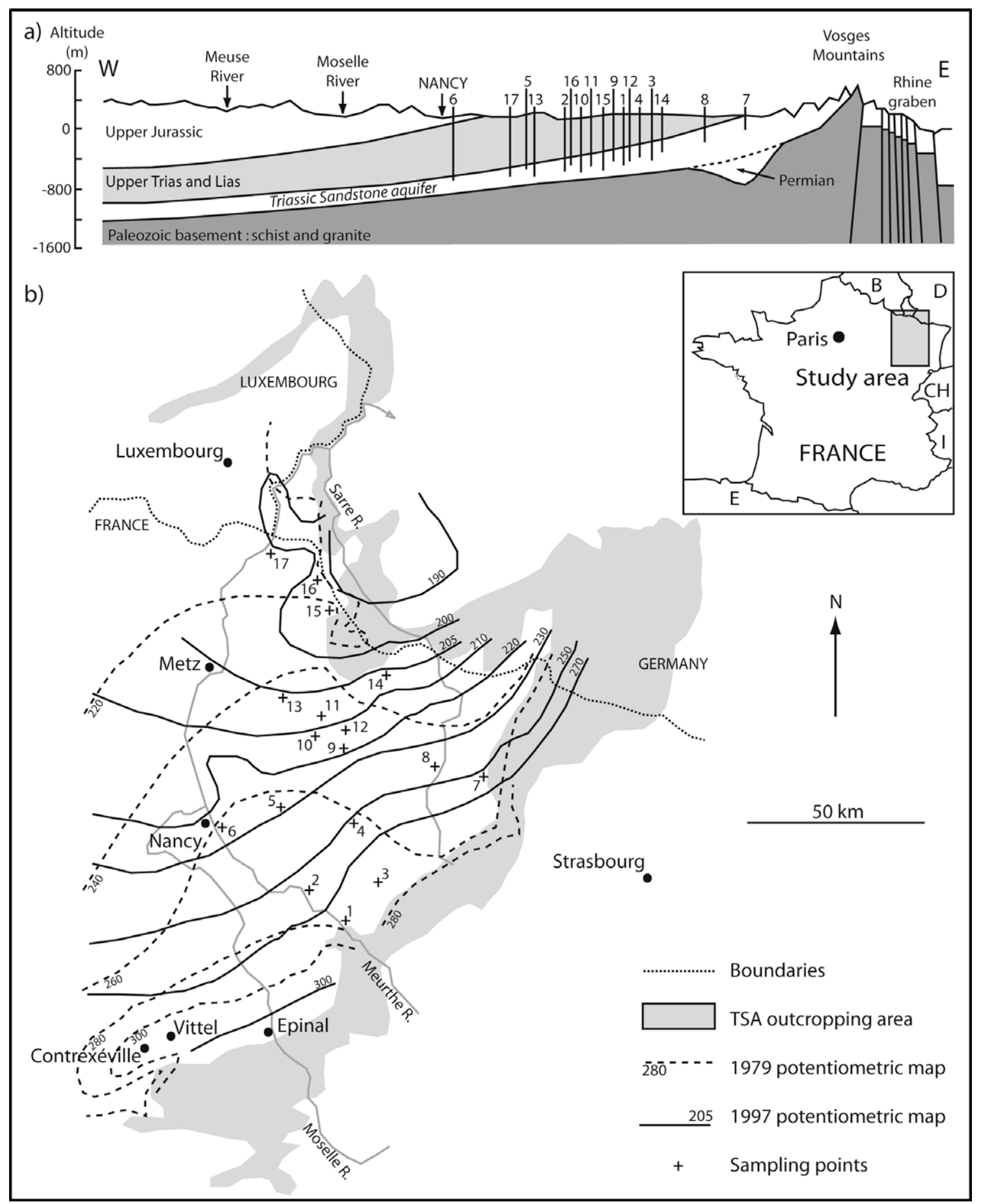

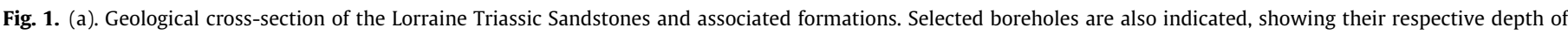

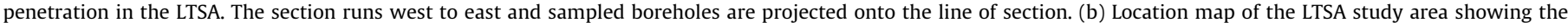
outcrop area and the equipotential lines for 1979 and 1997. Numbered sample sites refer to sample numbers in Tables.

the water supply of the Maginot Line. But it was mainly after 1948, with the development of the coal extraction industry, that the number of boreholes really began to increase rapidly. In the south of the Lorraine Region boreholes were created in the 1960s, around Vittel and Contrexéville, to ensure the development of the mineral and thermal water industry. In addition, numerous boreholes were constructed for drinking water supply (Vaute, 2004).

The aquifer storage coefficient varies from $4 \times 10^{-4}$ to $8 \times 10^{-5}$ in the confined part of the aquifer to $5 \times 10^{-2}$ to $5 \times 10^{-3}$ in the outcropping area. The associated transmissivity varies from 0.1 to $10^{-3} \mathrm{~m}^{2} / \mathrm{s}$ (Maïaux, 2006). The permeability is on average between 1 and $5 \times 10^{-5} \mathrm{~m} / \mathrm{s}$ (Vaute, 2004) and the effective porosity of the LTSA is around $10-15 \%$. Since the beginning of the 20th century, potentiometric heads have been strongly modified by the dewatering of coal mines close to the German border and by the development of many drinking water supply boreholes. The initial non-modified conditions of the potentiometric surface of the LTSA are not documented because of the rapid development of pumping in the early 1900s. In addition, most of the boreholes tapping the LTSA are designed for pumping and the measurements of the 


\begin{tabular}{|c|c|c|c|}
\hline \multirow{5}{*}{$\begin{array}{c}\text { Upper } \\
\text { Trias }\end{array}$} & \multirow{5}{*}{$\begin{array}{c}\text { Keuper } \\
(220-270 m)\end{array}$} & \multirow{2}{*}{ Upper Keuper (55-60m) } & Upper Keuper marls (35-40m) \\
\hline & & & Clay of Chanville $(20 \mathrm{~m})$ \\
\hline & & \multirow[b]{2}{*}{ Middle Keuper (15-30m) } & Dolomite (0-10m) \\
\hline & & & $\begin{array}{l}\text { Mottled marls }(15-55 \mathrm{~m}) \\
\text { Reed sandstone }\end{array}$ \\
\hline & & Lower Keuper (150m) & $\begin{array}{l}\text { Lower Keuper marls (100-150m) } \\
\text { Gypsum and halite }\end{array}$ \\
\hline & \multirow{3}{*}{$\begin{array}{l}\text { Lettenkohle } \\
(20-25 \mathrm{~m})\end{array}$} & & Dolomite $(2-5 \mathrm{~m})$ \\
\hline & & & Mottled marls (15m) \\
\hline & & & Lower dolomite (5m) \\
\hline \multirow{10}{*}{$\begin{array}{l}\text { Middle } \\
\text { Trias }\end{array}$} & \multirow{10}{*}{$\begin{array}{l}\text { Muschelkalk } \\
(220-285 \mathrm{~m})\end{array}$} & \multirow{3}{*}{ Upper Muschelkalk (60-65m) } & Limestone with Terebratulidae $(6 \mathrm{~m})$ \\
\hline & & & Limestone with Ceratites (45-50m) \\
\hline & & & Entrochal limestone $(8 \mathrm{~m})$ \\
\hline & & \multirow{7}{*}{ Middle Muschelkalk (90-125m) } & White limestone $(5-15 \mathrm{~m})$ \\
\hline & & & $\begin{array}{l}\text { Grey layers, gypsum and halite }(15-35 \mathrm{~m}) \\
\text { Grey layers, without gypsum and halite }(45 \mathrm{~m})\end{array}$ \\
\hline & & & $\begin{array}{lc}\text { Red layers }(25-50 \mathrm{~m}) & \Delta\end{array}$ \\
\hline & & & Dolomite (4-5m) \\
\hline & & & Wellenkalk (15m) \\
\hline & & & Marls with Myacites (30m) \\
\hline & & & Shelly sandstone (20-30m) \\
\hline \multirow{5}{*}{$\begin{array}{c}\text { Lower } \\
\text { Trias }\end{array}$} & \multirow{5}{*}{$\begin{array}{c}\text { Buntsandstein } \\
(400-500 \mathrm{~m})\end{array}$} & \multirow{3}{*}{ Variegated Sandstone $(80-90 \mathrm{~m})$} & Voltzia sandstone $(20 \mathrm{~m})$ \\
\hline & & & Intermediate layer $(60 \mathrm{~m})$ \\
\hline & & & Main conglomerate $(25 \mathrm{~m})$ \\
\hline & & \multirow{2}{*}{ Vosges Sandstone (300-400m) } & Upper Vosges Sandstone (150-200m) \\
\hline & & & $\begin{array}{l}\text { Lower Vosges Sandstone (150-200m) } \\
\text { Annweiler sandstone }\end{array}$ \\
\hline
\end{tabular}

$\Delta$ : gypsum; $\otimes:$ anhydrite; $\square:$ halite

Fig. 2. Lithologic column of the Trias formations of the Lorraine Basin.

Table 1

Chemical compositions of different Vosges sandstones: (I) siliceous sandstone, (II) conglomerate, (III) clay-enriched sandstone (after Probst et al., 1999).

\begin{tabular}{|c|c|c|c|c|c|c|c|c|c|c|c|c|}
\hline$\%$ & $\mathrm{SiO}_{2}$ & $\mathrm{Al}_{2} \mathrm{O}_{3}$ & $\mathrm{Fe}_{2} \mathrm{O}_{3}$ & $\mathrm{FeO}$ & $\mathrm{MnO}$ & $\mathrm{MgO}$ & $\mathrm{CaO}$ & $\mathrm{Na}_{2} \mathrm{O}$ & $\mathrm{K}_{2} \mathrm{O}$ & $\mathrm{Tio}_{2}$ & $\mathrm{P}_{2} \mathrm{O}_{5}$ & L.I. \\
\hline I & 94.90 & 3.64 & 1.00 & - & $<0.01$ & 0.07 & $<0.01$ & 0.02 & 2.45 & 0.05 & - & 0.69 \\
\hline II & 91.19 & 3.75 & 0.69 & 0.53 & 0.02 & 0.66 & - & 0.20 & 1.30 & 0.16 & 0.02 & 1.33 \\
\hline III & 81.30 & 7.06 & 1.60 & - & 0.01 & 0.30 & 0.87 & 0.21 & 4.40 & 0.41 & - & 3.20 \\
\hline
\end{tabular}

Table 2

Volume of the different kinds of groundwater uses and their locality for the year 2000 (after Vaute, 2004)

\begin{tabular}{llll}
\hline & Region & $\mathrm{Mm}^{3} \mathrm{a}^{-1}$ & $\%$ \\
\hline Drinking water - industrial water & Sarre (Germany) & 10.43 & 9.4 \\
& Moselle & 49.68 & 44.9 \\
& Meurthe-et-Moselle & 4.26 & 3.9 \\
& Vosges & 6.24 & 5.6 \\
Dewatering of coal mines & Sarre (Germany) & 2.29 & 2.1 \\
& Moselle & 37.67 & 34.1 \\
Total & & 110.57 & 100
\end{tabular}

potentiometric levels are not synchronous. As a result, the potentiometric map (Fig. 1) of the LTSA is only schematic. The general direction of groundwater flow is from the south to north (from the Vosges Mountains to the Sarre Region), and from the SW to the NE (from the Meuse River to the Moselle River). The hydraulic gradient varies strongly from $2 \times 10^{-2}$ to $5 \times 10^{-3}$ in the unconfined aquifer (according to the influence of the river drainage and the pumping rate) and from $10^{-4}$ to $1 \times 10^{-3}$ in the confined aquifer.
Table 3

Mean rainfall and throughfall compositions (after Probst et al., 1992).

\begin{tabular}{llllllllll}
\hline $\mathrm{mg} \mathrm{L}^{-1}$ & $\mathrm{pH}$ & $\mathrm{Na}^{+}$ & $\mathrm{K}^{+}$ & $\mathrm{Ca}^{2+}$ & $\mathrm{Mg}^{2+}$ & $\mathrm{Cl}^{-}$ & $\mathrm{SO}_{4}^{2-}$ & $\mathrm{NO}_{3}^{-}$ & $\mathrm{NH}_{4}^{+}$ \\
\hline Rainfall & 4.5 & 0.29 & 0.11 & 0.33 & 0.06 & 0.49 & 2.06 & 1.81 & 0.45 \\
Throughfall & 4.1 & 0.96 & 1.93 & 1.26 & 0.22 & 2.03 & 7.46 & 4.36 & 0.58 \\
\hline
\end{tabular}

The main recharge of the LTSA is provided by the precipitation that occurs in the outcropping zone (Vosges and Sarre regions). Rainfall provides the primary input of solutes and should be considered as representative of the minimum baseline concentration. In the forested zone, throughfall can also be considered as it locally represents water reaching the soil. Table 3 gives the average chemistry of rainfall and throughfall collected in the period from 1986 to 1989 in the Vosges Massif close to the aquifer recharge zone. Bulk precipitation is acidic with dominant ions being $\mathrm{SO}_{4}^{2-}$ and $\mathrm{NO}_{3}^{-}$that demonstrates anthropogenic aerosol influence during dissolution of atmospheric gases/aerosols (Celle-Jeanton et al., 2009). Throughfall water shows the same characteristics although it contains about five times greater concentrations of major ions. 


\section{Methodology}

In 1979, the first field campaign was carried out by Blavoux and Olive (1981). Using a detailed dataset of chemical (major ions) and isotopic measurements $\left({ }^{3} \mathrm{H}\right.$, radiocarbon, ${ }^{13} \mathrm{C},{ }^{18} \mathrm{O}$ and $\left.{ }^{2} \mathrm{H}\right)$, the authors evaluated the palaeohydrological regime of the LTSA.

The new campaign conducted in 2001 aimed at highlighting the chemical and isotopic variations related to the modification of potentiometric levels and circulation flow paths that occurred after large scale pumping. Detailed chemical (major ions and trace elements) and isotopic $\left({ }^{3} \mathrm{H}\right.$, radiocarbon, ${ }^{13} \mathrm{C},{ }^{18} \mathrm{O}$ and $\left.{ }^{2} \mathrm{H}\right)$ analysis were performed on 17 regularly pumped boreholes (Fig. 1, Table 4). Field parameters included temperature $\left(\mathrm{T}^{\circ} \mathrm{C}\right)$, specific electrical conductance (SEC), alkalinity, $\mathrm{pH}$, dissolved $\mathrm{O}_{2}$ (DO), and Eh were measured as far as possible in anaerobic conditions. Samples were filtered through $0.45 \mu \mathrm{m}$ membranes and were collected for major and trace element analysis in polyethylene bottles. The aliquot for cation and trace element analysis were acidified to $\mathrm{pH}<2$ with $1 \%$ $\mathrm{v} / \mathrm{v} \mathrm{HNO}_{3}$. Additional samples were collected in glass bottles for stable isotopes and polyethylene bottles for ${ }^{3} \mathrm{H}$ and ${ }^{14} \mathrm{C}$ (precipitation method).

Major anions and cations were determined by ion chromatography and atomic absorption spectrometry (Hydrogeology Depart- ment of the University of Avignon); trace elements by ICPMS (British Geological Survey); stable isotope and ${ }^{14} \mathrm{C}$ analyses were completed both in the Hydrogeology Department of the University of Avignon and the Geochemistry and Isotope Hydrology Laboratory of the University of Paris XI, by mass spectrometry and conventional counting.

\section{Results and discussion}

Results of the current sampling are shown in Tables 5 and 6 . Groundwater well-head temperatures range between $10.6^{\circ} \mathrm{C}$ and $32.1^{\circ} \mathrm{C}$. There is good correlation between temperature and well depth (Fig. 3), which indicates that the water is derived from the main horizon of the aquifer without rapid leakage from overlying formations. Therefore in the present study temperature is used as a proxy for depth and also age (see following discussion). This procedure is the same as that adopted for the UK East Midlands aquifer (Edmunds et al., 1982).

SEC varies from 175 to $1289 \mu \mathrm{S} \mathrm{cm}^{-1}$ (Table 5) with a median value of $735 \mu \mathrm{S} \mathrm{cm}^{-1}$. The reported $\mathrm{pH}$ values measured at well head are generally between 6.7 and 8.5 . With the exception of two points (Langatte and Moussey with $\mathrm{pH}$ of 8.5 and 8.0, respectively), the waters are relatively well buffered at circumneutral $\mathrm{pH}$

Table 4

Well locations.

\begin{tabular}{|c|c|c|c|c|c|c|c|}
\hline Well ID & Location & Date of sampling & $\mathrm{X}^{\mathrm{a}}(\mathrm{km})$ & $\mathrm{Y}^{\mathrm{a}}(\mathrm{km})$ & $\mathrm{Z}^{\mathrm{a}}(\mathrm{m})$ & Depth (m) & Distance $^{\mathrm{b}}(\mathrm{km})$ \\
\hline 1 & Gélacourt & 03/07/2001 & 924,775 & $2,395,919$ & 279 & 225 & 10 \\
\hline 2 & Saint-Clément & $03 / 07 / 2001$ & 915,444 & $2,401,152$ & 250 & 319 & 20 \\
\hline 3 & Blamont & $05 / 07 / 2001$ & 933,229 & $2,408,812$ & 267 & 243 & 11 \\
\hline 4 & Moussey & $04 / 07 / 2001$ & 927,209 & $2,417,931$ & 240 & 340 & 22 \\
\hline 5 & Bathélémont & $05 / 07 / 2001$ & 906,622 & $2,418,790$ & 256 & 550 & 43 \\
\hline 6 & Tomblaine & 05/07/2001 & 885,353 & $2,416,786$ & 204 & 708 & 49 \\
\hline 7 & Saint-Louis & $03 / 07 / 2001$ & 959,107 & $2,423,302$ & 227 & 122 & 0 \\
\hline 8 & Langatte & $02 / 07 / 2001$ & 940,278 & $2,427,163$ & 255 & 360 & 16 \\
\hline 9 & Dieuze & $29 / 06 / 2001$ & 922,541 & $2,431,899$ & 210 & 820 & 34 \\
\hline 10 & Puttigny & 29/06/2001 & 909,753 & $2,435,881$ & 210 & 850 & 47 \\
\hline 11 & Morhange & $29 / 06 / 2001$ & 914,936 & $2,444,424$ & 245 & 800 & 48 \\
\hline 12 & Rodalbe & $29 / 06 / 2001$ & 919,194 & $2,444,064$ & 268 & 428 & 44 \\
\hline 13 & Holacourt & $28 / 06 / 2001$ & 906,091 & $2,449,258$ & 232 & 759 & 57 \\
\hline 14 & Hellimer & $28 / 06 / 2001$ & 928,717 & $2,453,347$ & 228 & 800 & 43 \\
\hline 15 & Guerting & $27 / 06 / 2001$ & 913,525 & $2,474,150$ & 230 & 143 & 0 \\
\hline 16 & Dalem & $27 / 06 / 2001$ & 910,476 & $2,479,963$ & 238 & 120 & 0 \\
\hline 17 & Kirschnaumen & $26 / 06 / 2001$ & 896,415 & $2,498,723$ & 320 & 290 & 0 \\
\hline
\end{tabular}

nd: Not determined.

a Lambert II "étendu" coordinates.

b Distance from recharge area along the flowlines.

Table 5

Field parameters and water chemistry data.

\begin{tabular}{|c|c|c|c|c|c|c|c|c|c|c|c|c|c|c|c|}
\hline $\begin{array}{l}\text { Well } \\
\text { ID }\end{array}$ & Location & $\begin{array}{l}\mathrm{T} \\
\left({ }^{\circ} \mathrm{C}\right)\end{array}$ & $\begin{array}{l}\mathrm{SEC}(\mu \mathrm{S} / \\
\mathrm{cm})\end{array}$ & $\begin{array}{l}\text { Eh } \\
(\mathrm{mV})\end{array}$ & $\mathrm{pH}$ & $\begin{array}{l}\mathrm{HCO}_{3}^{-} \\
(\mathrm{mg} / \mathrm{L})\end{array}$ & $\begin{array}{l}\mathrm{SO}_{4}^{2-} \\
(\mathrm{mg} / \mathrm{L})\end{array}$ & $\begin{array}{l}\mathrm{Cl}^{-} \\
(\mathrm{mg} / \mathrm{L})\end{array}$ & $\begin{array}{l}\mathrm{NO}_{3}^{-} \\
(\mathrm{mg} / \mathrm{L})\end{array}$ & $\begin{array}{l}\mathrm{Ca}^{2+} \\
(\mathrm{mg} / \mathrm{L})\end{array}$ & $\begin{array}{l}\mathrm{Mg}^{2+} \\
(\mathrm{mg} / \mathrm{L})\end{array}$ & $\begin{array}{l}\mathrm{Na}^{+} \\
(\mathrm{mg} / \mathrm{L})\end{array}$ & $\begin{array}{l}\mathrm{K}^{+} \\
(\mathrm{mg} / \mathrm{l})\end{array}$ & $\begin{array}{l}\mathrm{SiO}_{2} \\
(\mathrm{mg} / \mathrm{l})\end{array}$ & $\begin{array}{l}\text { IB } \\
(\%)\end{array}$ \\
\hline 1 & Gélacourt & 16.1 & 287 & 124 & 6.83 & 121 & 15.90 & 18.80 & 3.60 & 14.09 & 8.38 & 36.74 & 5.81 & 18.4 & 3.97 \\
\hline 2 & Saint-Clément & 20.5 & 826 & 190 & 7.25 & 266 & 54.30 & 118.00 & 4.70 & 67.30 & 38.17 & 56.46 & 8.03 & 16.9 & 1.48 \\
\hline 3 & Blamont & 16.2 & 219 & 217 & 7.49 & 138 & 3.31 & 4.50 & 0 & 26.90 & 12.89 & 2.66 & 2.98 & 16.8 & 2.75 \\
\hline 4 & Moussey & 20.0 & 338 & 174 & 8.03 & 149 & 11.20 & 40.8 & 1.44 & 19.98 & 14.35 & 31.61 & 3.57 & 16.2 & 2.71 \\
\hline 5 & Bathélémont & 29.7 & 895 & 21 & 7.50 & 240 & 51.80 & 157.70 & 0 & 62.74 & 29.65 & 84.56 & 9.01 & 21.4 & 0.08 \\
\hline 6 & Tomblaine & 32.1 & 194 & -138 & 7.15 & 282 & 111.00 & 522.00 & 0 & 88.12 & 21.60 & 301.68 & 17.06 & 24.0 & 4.62 \\
\hline 7 & Saint-Louis & 12.9 & 175 & 164 & 7.28 & 100 & 1.11 & 2.56 & 0 & 20.82 & 10.63 & 1.64 & 3.40 & 16.0 & 8.83 \\
\hline 8 & Langatte & 19.9 & 925 & 140 & 8.54 & 153 & 19.10 & 223.6 & 1.60 & 8.00 & 3.72 & 184.12 & 3.40 & 17.0 & 2.36 \\
\hline 9 & Dieuze & 25.7 & 644 & 208 & 7.82 & 131 & 27.72 & 128.6 & 0 & 29.47 & 17.70 & 80.22 & 5.10 & 20.2 & 1.59 \\
\hline 10 & Puttigny & 29.7 & 1040 & -114 & 7.80 & 157 & 113.00 & 201.2 & 1.21 & 43.38 & 16.04 & 151.62 & 7.66 & 22.4 & 1.67 \\
\hline 11 & Morhange & 28.3 & 596 & 201 & 7.51 & 165 & 42.75 & 95.21 & 0 & 36.97 & 19.66 & 54.33 & 7.93 & 23.4 & 2.04 \\
\hline 12 & Rodalbe & 26.1 & 833 & 152 & 7.84 & 137 & 47.90 & 188.1 & 0 & 34.49 & 18.95 & 105.10 & 6.44 & 21.4 & 3.16 \\
\hline 13 & Holacourt & 26.1 & 1022 & -62 & 7.56 & 195 & 108.3 & 185 & 0 & 60.08 & 20.82 & 116.68 & 8.90 & 20.2 & 3.18 \\
\hline 14 & Hellimer & 31.3 & 1289 & -20 & 7.85 & 140 & 58.00 & 330 & 2.45 & 46.80 & 23.84 & 170.14 & 7.94 & 23.2 & 3.81 \\
\hline 15 & Guerting & 10.6 & 281 & 61 & 6.84 & 123 & 37.82 & 7.18 & 0 & 32.15 & 13.4 & 2.33 & 2.58 & 18.5 & 2.32 \\
\hline 16 & Dalem & 11.5 & 626 & 362 & 6.73 & 314 & 100.56 & 9.17 & 2.17 & 102.4 & 25.92 & 3.54 & 3.25 & 14.3 & 0.34 \\
\hline 17 & Kirschnaumen & 13.6 & 1026 & 679 & 6.89 & 345 & 313.86 & 15.04 & 14.28 & 188.44 & 42.24 & 5.36 & 3.84 & 19.3 & 1.36 \\
\hline
\end{tabular}



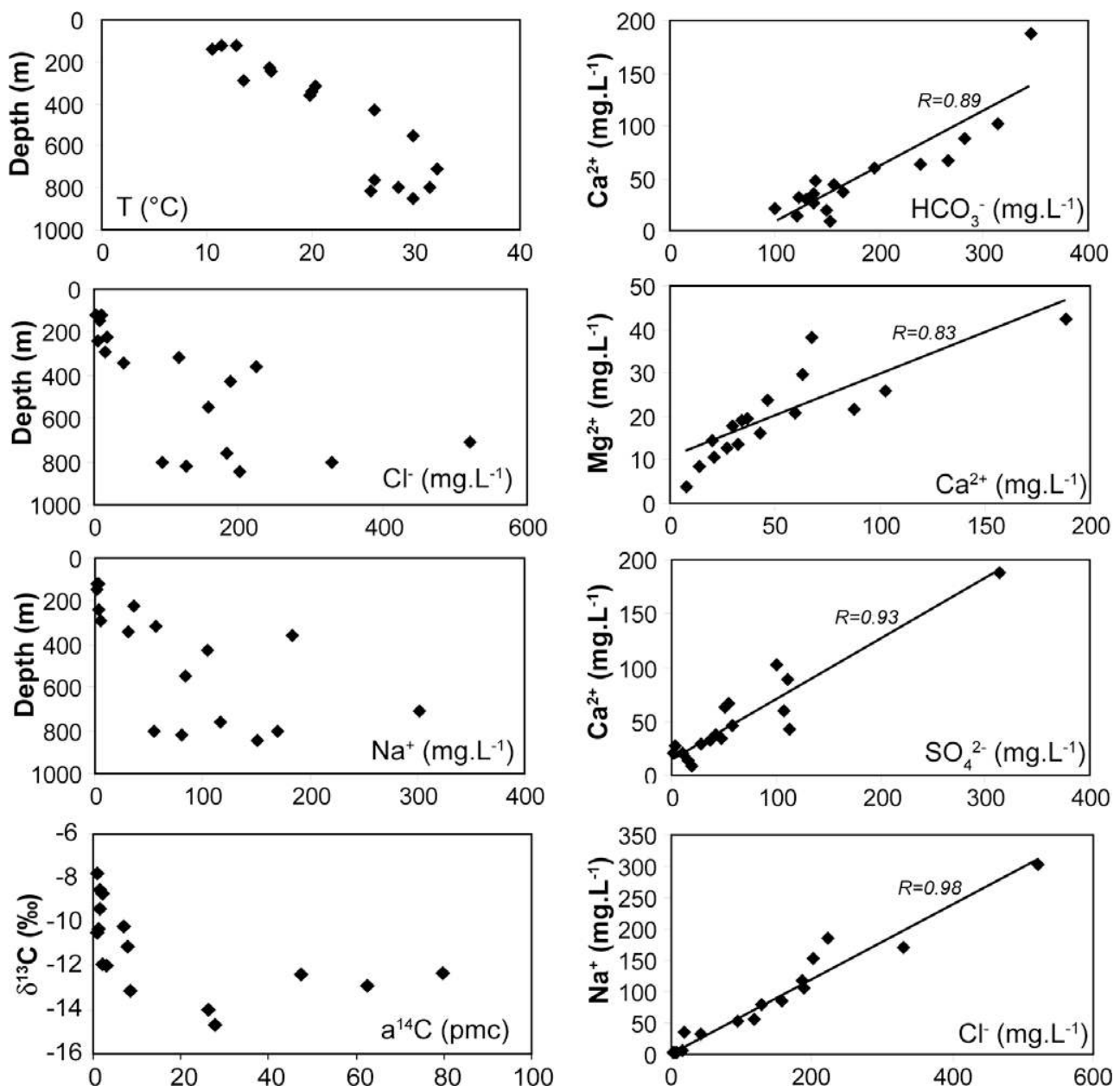

Fig. 3. Plots of groundwater $\mathrm{T}^{\circ} \mathrm{C}, \mathrm{Na}^{+}$and $\mathrm{Cl}^{-}$against depth for the LTSA. Relationship between $\delta^{13} \mathrm{C} \mathrm{a}^{14} \mathrm{C} \mathrm{Ca}^{2+} / \mathrm{HCO}_{3}^{-}, \mathrm{Mg}^{2+} / \mathrm{Ca}^{2+}, \mathrm{Ca}^{2+} / \mathrm{SO}_{4}^{2-}, \mathrm{Na}^{+} / \mathrm{Cl}^{-}$.

with a median value of 7.35. Many groundwaters contain significant concentrations of DO and widely variable Eh, not always well correlated, highlighting the difficulties of measurement. The aquifer seems mostly oxidising with moderately reducing zones without a clear redox boundary. Nevertheless redox potentials can reach $692 \mathrm{mV}$ near the recharge area (Fig. 4); in the deepest parts of the aquifer, where boreholes penetrate the sandstone to depths of $800 \mathrm{~m}$ below ground level (Table 4) some of the more evolved water has negative measured Eh values. The results are discussed further following establishment of the age relationships.

\subsection{Groundwater age distribution from isotopic data}

\subsubsection{Stable isotopes}

Stable isotopes $\left(\delta^{18} \mathrm{O}, \delta^{2} \mathrm{H}\right)$ have conservative properties and depend only on atmospheric conditions during recharge (Gat, 1971). Consequently, they provide information on the recharge processes of groundwater and help to resolve questions relating to residence times and origins. The residence time of groundwater in actively circulating systems may range from tens to thousands of years and changing climate should be recorded in palaeogroundwaters. Such climate changes are manifested by a shift in the stable isotope content of precipitation; the use of the isotopic method is then an important tool to distinguish Holocene waters and Pleistocene waters that could circulate in the deeper confined parts of the aquifer (Darling et al., 1997). Late Pleistocene palaeogroundwaters from temperate regions will be isotopically depleted with respect to modern waters and shifted along the Global Meteoric Water Line (GMWL) towards negative values.

The nearest relevant IAEA/WMO GNIP station is Karlsruhe for which there is a continuous temporal record of monthly means of $\delta^{18} \mathrm{O}$ and $\delta^{2} \mathrm{H}$ for rainfall covering the period 1981-2001 (IAEA/WMO, 2006). The $\delta^{18} \mathrm{O}$ and $\delta^{2} \mathrm{H}$ compositions of groundwater range from $-8.19 \%$ o to $-10.81 \%$ and from $-57.1 \%$ o to $-72.9 \%$, respectively. In the $\delta^{2} \mathrm{H}$ versus $\delta^{18} \mathrm{O}$ diagram (Fig. 6, Table 7 ), all the groundwaters are situated along the GMWL defined by Craig (1961) and along the Karlsruhe Local Water Line. A mixing line could be observed between two extreme values ([-8.5 $\delta^{18} \mathrm{O} \%$, $-57 \delta^{2} \mathrm{H} \%$ o]; [-10.4 $\delta^{18} \mathrm{O} \%$, $-67 \delta^{2} \mathrm{H} \%$ o]). The more enriched isotopic compositions correspond to modern waters that are sampled near the recharge zone $(\leqslant 15 \mathrm{~km})$. These values are close to the weighted mean values for modern rainfall in Karlsruhe $\left(\delta^{18} \mathrm{O}=-8.11 \%, \quad n=245, \quad \sigma=2.48 \quad / \delta^{2} \mathrm{H}=-57.17, \quad n=245\right.$, $\sigma=19.39$ ). The more impoverished waters are about $-2 \delta^{18} \mathrm{O} \%$ and $-10 \delta^{2} \mathrm{H} \%$ lighter than modern rainfall and must represent a cooler regime. Intermediate $\delta^{18} \mathrm{O}$ and $\delta^{2} \mathrm{H}$ values (Hellimer, Langatte, Saint-Clément and Gélacourt) can be explained by a mixing between Pleistocene and Holocene waters. Corresponding low ${ }^{14} \mathrm{C}$ activities and low $\mathrm{NO}_{3}^{-}$concentrations in these boreholes reinforce this hypothesis.

\subsubsection{Carbonate system evolution and carbon isotopes}

The total dissolved inorganic $\mathrm{C}$ (TDIC) is equivalent to the groundwater $\mathrm{HCO}_{3}^{-}$content for the observed $\mathrm{pH}$ range. Most samples are close to calcite saturation or clearly oversaturated, with 

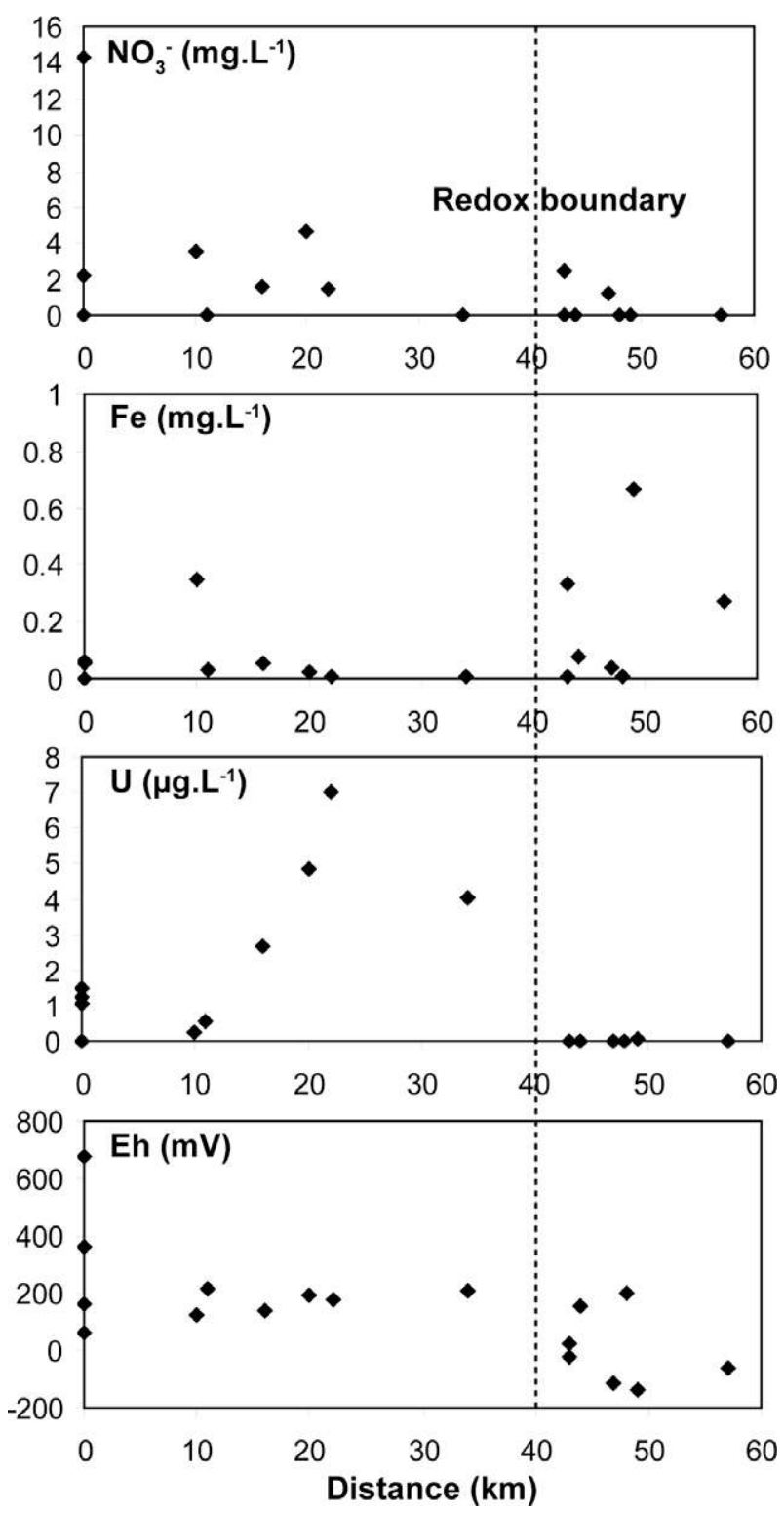

Fig. 4. Downgradient trends for redox parameters $\mathrm{NO}_{3}^{-}, \mathrm{Fe}, \mathrm{U}, \mathrm{Eh}$. saturation indices $\mathrm{SI}_{\text {calcite }}=-1.47$ to 0.22 (Table 8 ). Guerting and Gélacourt are strongly undersaturated. There is little variation in TDIC although some increase is observed for the most evolved waters (Fig. 5). The slightly higher concentration in $\mathrm{HCO}_{3}^{-}$for evolved waters may be caused by carbonate dissolution driven by cation exchange or by incongruent reaction of the carbonate matrix. Since $\delta^{13} \mathrm{C}$ content becomes more enriched along the flow line (Fig. 5), alkalinity is more likely to result from carbonate dissolution (Elliot et al., 1999).

Ion exchange-induced dissolution of primary marine carbonate of the matrix is also likely to be of limited extent in the aquifer, reflected only in a slight increase in $\mathrm{pH}$ for the most evolved waters. Adjustment of $\mathrm{HCO}_{3}^{-}$at equilibrium due to incongruent dissolution may be the explanation. Least evolved groundwaters have $\delta^{13} \mathrm{C}$ values close to $-13 \%$, in good agreement with simple congruent reaction between dissolved soil $\mathrm{CO}_{2}$ and the carbonate matrix. Groundwater evolution then takes place generally under closedsystem conditions with respect to atmospheric $\mathrm{CO}_{2}$. The enrichment in $\delta^{13} \mathrm{C}$ content is then linked to incongruent dissolution reactions of the aquifer matrix under closed-system conditions.

Downgradient trends in the $\mathrm{C}$ isotopic contents of TDIC show heavier $\delta^{13} \mathrm{C}$ values corresponding with diminishing values of ${ }^{14} \mathrm{C}$ activities towards the centre of the aquifer. Groundwater with more than $50 \%$ of modern $C$ after congruent dissolution must be of recent origin and some of these may also contain an input of ${ }^{14} \mathrm{C}$ from thermonuclear weapon tests. Under closed-system conditions, decay of radiocarbon from an activity of $50 \%$ would evolve according to an exponential law. The more evolved waters have clearly undergone incongruent dissolution exchange and/or mixing with an evolved $\delta^{13} \mathrm{C}$-rich TDIC source. Their ${ }^{14} \mathrm{C}$ specific activities decrease toward insignificant values as $\delta^{13} \mathrm{C}$ increases (Fig. 3). Mixed signatures may occur where high ${ }^{14} \mathrm{C}$-content waters mix directly with more evolved waters, possibly due to admixing of a rapid flow path from recharge into the aquifer or as a result of a faulty borehole lining giving rise to bypass flow (Blamont). However the site (Saint-Louis) showing this behaviour is an unconfined site and may simply reflect open system evolution (Table 7).

\subsubsection{Age calculation}

Groundwater residence times based on ${ }^{14} \mathrm{C}$ activity of TDIC can be estimated provided that dilution of the ${ }^{14} \mathrm{C}$ by inactive $\mathrm{C}$ of the matrix can be evaluated. Many correction models have been proposed which are based on chemical evolution and/or isotope dilution of ${ }^{13} \mathrm{C} /{ }^{12} \mathrm{C}$ derived from soil $\mathrm{CO}_{2}$ through interactions with

Table 6

Selected trace element data $(\mu \mathrm{g} / \mathrm{L})$.

\begin{tabular}{|c|c|c|c|c|c|c|c|c|c|c|c|c|c|c|c|c|c|c|c|c|c|c|}
\hline Well ID & Location & $\mathrm{P}$ & $\mathrm{Al}$ & As & B & $\mathrm{Ba}$ & $\mathrm{Br}(\mathrm{mg} / \mathrm{L})$ & Cs & $\mathrm{Cu}$ & $\mathrm{Fe}(\mathrm{mg} / \mathrm{L})$ & $\mathrm{Li}$ & $\mathrm{Mn}(\mathrm{mg} / \mathrm{L})$ & Mo & $\mathrm{Pb}$ & $\mathrm{Rb}$ & Sc & Se & Sn & $\mathrm{Sr}$ & $\mathrm{U}$ & $\mathrm{Zn}$ & $\mathrm{Br} / \mathrm{Cl}$ \\
\hline 1 & Gélacourt & 35 & 13 & 1 & $<20$ & 48.31 & 0.078 & 3.81 & 0.5 & 0.352 & 25 & 0.056 & $<.1$ & 0.4 & 12.95 & 3.25 & $<.5$ & 0.43 & 38.38 & 0.24 & 8.8 & 0.0042 \\
\hline 2 & Saint-Clément & $<20$ & 12 & $<1$ & $<20$ & 97.04 & 0.103 & 5.12 & 2.1 & 0.022 & 37 & 0.003 & $<.1$ & 0.9 & 19.21 & 3.54 & 0.6 & 0.33 & 392.52 & 4.84 & 10.3 & 0.0009 \\
\hline 3 & Blamont & 22 & 10 & 10 & $<20$ & 64.92 & 0.027 & 0.71 & 2.5 & 0.034 & 15 & $<0.002$ & 0.1 & 0.8 & 5.19 & 4.04 & $<.5$ & 0.51 & 63.84 & 0.58 & 6.3 & 0.0060 \\
\hline 4 & Moussey & $<20$ & 6 & 4 & $<20$ & 222.85 & 0.150 & 1.29 & 0.3 & 0.010 & 12 & $<0.002$ & 0.2 & $<.1$ & 5.38 & 3.32 & 0.7 & 0.57 & 62.83 & 7.00 & 2.4 & 0.0037 \\
\hline 5 & Bathélémont & $<20$ & 2 & 13 & $<20$ & 114.01 & 0.100 & 4.29 & 0.6 & 0.332 & 51 & 0.005 & 0.2 & $<.1$ & 15.01 & 4.65 & 1.0 & 0.48 & 514.20 & $<.05$ & 3.9 & 0.0006 \\
\hline 6 & Tomblaine & $<20$ & 6 & 20 & 204 & 72.81 & 0.348 & 8.65 & 1.6 & 0.663 & 600 & 0.042 & 4.1 & $<.1$ & 45.44 & 5.70 & 9.7 & 0.46 & 2533.42 & 0.08 & 3.7 & 0.0007 \\
\hline 7 & Saint-Louis & 114 & 3 & 10 & $<20$ & 43.11 & 0.015 & 0.35 & 3.6 & $<0.005$ & 13 & $<0.002$ & $<.1$ & 0.9 & 3.73 & 3.37 & $<.5$ & 0.19 & 19.27 & 1.04 & 12.9 & 0.0059 \\
\hline 8 & Langatte & 67 & 12 & 18 & $<20$ & 125.01 & 0.243 & 1.12 & 1.7 & 0.057 & 13 & 0.003 & 0.4 & 0.5 & 4.37 & 4.12 & $<.5$ & 1.10 & 40.27 & 2.68 & 77.3 & 0.0011 \\
\hline 9 & Dieuze & $<20$ & 4 & 8 & $<20$ & 81.95 & 0.080 & 1.63 & 4.4 & 0.005 & 23 & $<0.002$ & 0.2 & 0.2 & 7.74 & 3.95 & 0.8 & 0.21 & 119.15 & 4.03 & 13.6 & 0.0006 \\
\hline 10 & Puttigny & $<20$ & 5 & 6 & 26 & 73.30 & 0.214 & 1.85 & 1.0 & 0.038 & 88 & 0.016 & 1.0 & 0.1 & 13.94 & 5.92 & 0.5 & 0.17 & 421.32 & $<.05$ & 4.0 & 0.0011 \\
\hline 11 & Morhange & $<20$ & 11 & 2 & $<20$ & 93.08 & 0.051 & 1.93 & 1.6 & 0.008 & 46 & $<0.002$ & 0.4 & 1.0 & 12.78 & 4.67 & $<.5$ & 0.31 & 242.75 & $<.05$ & 7.5 & 0.0005 \\
\hline 12 & Rodalbe & $<20$ & 4 & 4 & $<20$ & 95.89 & 0.142 & 2.45 & 1.2 & 0.074 & 31 & 0.009 & 0.4 & 1.2 & 9.58 & 5.75 & $<.5$ & 0.21 & 326.44 & $<.05$ & 5.9 & 0.0008 \\
\hline 13 & Holacourt & 28 & 5 & 5 & 24 & 62.69 & 0.134 & 2.32 & 1.0 & 0.272 & 93 & 0.009 & 0.5 & $<.1$ & 18.46 & 5.47 & 1.1 & 0.42 & 785.17 & $<.05$ & 11.2 & 0.0007 \\
\hline 14 & Hellimer & $<20$ & 3 & 14 & $<20$ & 181.74 & 0.300 & 3.13 & 3.3 & 0.011 & 45 & 0.016 & 0.5 & $<.1$ & 12.5 & 6.28 & 0.6 & 0.14 & 667.50 & $<.05$ & 4.5 & 0.0009 \\
\hline 15 & Guerting & 31 & 2 & 6 & $<20$ & 71.17 & 0.030 & 0.68 & 0.4 & 5.480 & 8 & 0.223 & $<.1$ & 0.2 & 6.09 & 4.62 & $<.5$ & 0.55 & 51.79 & $<.05$ & 256.3 & 0.0042 \\
\hline 16 & Dalem & 29 & 5 & 1 & 33 & 85.96 & 0.031 & 1.32 & 1.3 & 0.053 & 20 & 0.038 & 0.5 & 8.5 & 9.66 & 4.26 & $<.5$ & 0.31 & 606.20 & 1.50 & 470.2 & 0.0034 \\
\hline 17 & Kirschnaumen & $<20$ & 28 & $<1$ & 54 & 25.12 & 0.086 & 3.55 & 2.5 & 0.059 & 35 & 0.003 & 1.2 & 0.1 & 15.01 & 5.48 & 0.5 & 0.26 & 1081.72 & 1.21 & 34.3 & 0.0057 \\
\hline
\end{tabular}


Table 7

Isotope data.

\begin{tabular}{|c|c|c|c|c|c|c|}
\hline Well ID & Location & ${ }^{3} \mathrm{H}(\mathrm{TU})$ & $\mathrm{a}^{14} \mathrm{C}(\mathrm{pmc})$ & $\delta^{13} \mathrm{C}(\% o)$ & $\delta^{18} \mathrm{O}(\%)$ & $\delta \mathrm{D}(\% o)$ \\
\hline 1 & Gélacourt & nd & nd & -9.2 & -9.79 & -67.0 \\
\hline 2 & Saint-Clément & nd & $7.0 \pm 0.3$ & -10.2 & -10.05 & -64.0 \\
\hline 3 & Blamont & $<1.6$ & $27.7 \pm 0.5$ & -14.7 & -8.19 & -58.3 \\
\hline 4 & Moussey & $<1.3$ & $8.4 \pm 0.9$ & -13.1 & -10.81 & -72.9 \\
\hline 5 & Bathélémont & nd & $1.3 \pm 0.3$ & -10.3 & -9.38 & -63.6 \\
\hline 6 & Tomblaine & nd & $1.4 \pm 0.2$ & -8.5 & -9.79 & -64.9 \\
\hline 7 & Saint-Louis & $<1.2$ & $26.4 \pm 0.5$ & -14.0 & -8.59 & -63.4 \\
\hline 8 & Langatte & nd & $8.0 \pm 0.3$ & -11.1 & -9.96 & -66.3 \\
\hline 9 & Dieuze & nd & $3.0 \pm 0.3$ & -12.0 & -10.17 & -68.6 \\
\hline 10 & Puttigny & nd & $1.4 \pm 0.2$ & -9.4 & -10.24 & nd \\
\hline 11 & Morhange & nd & $0.8 \pm 0.2$ & -7.8 & nd & -66.9 \\
\hline 12 & Rodalbe & nd & $2.1 \pm 0.3$ & -8.7 & -10.24 & -67.6 \\
\hline 13 & Holacourt & nd & $0.9 \pm 0.3$ & -10.5 & -9.78 & -66.4 \\
\hline 14 & Hellimer & nd & $2.0 \pm 0.2$ & -11.9 & -9.32 & -68.5 \\
\hline 15 & Guerting & $3.4 \pm 0.8$ & $47.5 \pm 0.9$ & -12.4 & -9.02 & -57.7 \\
\hline 16 & Dalem & $4.4 \pm 0.8$ & $79.8 \pm 0.7$ & -12.3 & -8.92 & -56.9 \\
\hline 17 & Kirschnaumen & $6.0 \pm 1.0$ & $62.4 \pm 0.6$ & -12.9 & 88.52 & -57.1 \\
\hline
\end{tabular}

nd: Not determined.

Table 8

Saturation indexes for commonly occurring minerals calculated using PHREEQ-C for groundwaters in the LTSA.

\begin{tabular}{|c|c|c|c|c|c|c|c|c|}
\hline Well ID & Location & Barite & Celestite & Gypsum & Quartz & Chalcedony & Calcite & Dolomite \\
\hline 1 & Gélacourt & -0.39 & -3.79 & -2.92 & 0.44 & -0.02 & -1.47 & -2.93 \\
\hline 2 & Saint-Clément & 0.12 & -2.48 & -1.95 & 0.40 & -0.05 & -0.08 & 0.11 \\
\hline 3 & Blamont & -0.95 & -4.26 & -3.34 & 0.44 & -0.02 & -0.46 & -1.02 \\
\hline 4 & Moussey & 0.01 & -3.77 & -2.97 & 0.36 & -0.09 & 0.00 & 0.15 \\
\hline 5 & Bathélémont & 0.02 & -2.37 & -2.01 & 0.35 & -0.07 & 0.22 & 0.52 \\
\hline 6 & Tomblaine & 0.00 & -1.47 & -1.65 & 0.06 & -0.35 & 0.04 & -0.11 \\
\hline 7 & Saint-Louis & -1.50 & -5.22 & -3.88 & 0.48 & 0.01 & -0.95 & -2.03 \\
\hline 8 & Langatte & -0.01 & -3.80 & -3.21 & 0.36 & -0.08 & 0.05 & 0.06 \\
\hline 9 & Dieuze & -0.22 & -3.17 & -2.49 & 0.36 & -0.06 & -0.05 & 0.03 \\
\hline 10 & Puttigny & 0.15 & -2.10 & -1.81 & 0.36 & -0.05 & 0.16 & 0.28 \\
\hline 11 & Morhange & -0.04 & -2.69 & -2.22 & 0.38 & -0.03 & -0.13 & -0.15 \\
\hline 12 & Rodalbe & 0.03 & -2.54 & -2.23 & 0.39 & -0.04 & 0.03 & 0.17 \\
\hline 13 & Holacourt & 0.11 & -1.87 & -1.71 & 0.37 & -0.05 & 0.11 & 0.12 \\
\hline 14 & Hellimer & 0.24 & -2.21 & -2.03 & 0.35 & -0.06 & 0.21 & 0.55 \\
\hline 15 & Guerting & 0.21 & -3.31 & -2.22 & 0.54 & 0.06 & -1.19 & -2.63 \\
\hline 16 & Dalem & 0.49 & -2.00 & -1.48 & 0.45 & -0.02 & -0.48 & -1.40 \\
\hline 17 & Kirschnaumen & 0.21 & -1.42 & -0.88 & 0.53 & 0.07 & -0.07 & -0.61 \\
\hline
\end{tabular}

aquifer carbonates. The results of age calculation with several models described in the literature are given in Table 9. Ages proposed by Fontes and Garnier (1979), Evans et al. (1979), Ingerson and Pearson (1964) and Eichinger (1983) are all in good agreement and provide very similar solutions. The models of Tamers (1975), IAEA (Salem et al., 1980) and Mook (1980) tend to give rise to over-estimations of groundwater residence times.

In this paper, ${ }^{14} \mathrm{C}$ activities results (Table 7) were corrected using the Fontes and Garnier (1979) model. This model provides an adequate age estimation taking into account the timing of the Last Glacial Maximum (around $18 \mathrm{ka}$ ago) and well adapted to the geochemical reactions experienced by groundwater within the aquifer. Corrections used measured $\delta^{13} \mathrm{C}$ values for TDIC and values for soil $\mathrm{CO}_{2}$ and the mineral phase of $-22 \%$ (Fleyfel and Bakalowicz, 1980; Dever, 1985; Eichinger, 1987; Merlot et al., 1996), and 0\%o, respectively. The Fontes and Garnier (1979) model assumes closed-system carbonate reaction, dilution of the aquifer matrix and continued isotopic disequilibrium between dissolved and solid carbonate.

Groundwaters have been sub-divided into unevolved and evolved groundwaters using both $\mathrm{a}^{14} \mathrm{C}$ and $\delta^{13} \mathrm{C}$ criteria, which corresponds also to the subdivision into groups with stable isotopes of the water molecule (Table 9). All applied correction models (which are essentially based on isotope dilution) suggest Holocene or modern ages for unevolved waters (with predominantly light $\delta^{13} \mathrm{C}$ ); their ages range from modern to approximately $8 \mathrm{ka}$. All of the evolved groundwaters (mostly heavy $\delta^{13} \mathrm{C}$ ) have modelled ages which suggest Late Pleistocene recharge (Table 10). The oldest modelled ages range from 25 to $30 \mathrm{ka}$.

Fig. 7 shows a good correlation between ${ }^{14} \mathrm{C}$ model ages and groundwater temperatures. Groundwaters increase in age (Fig. 7) and temperature (Fig. 5) along the main flow line. So temperature appears to be a good index to separate waters according to their maturity and residence time in the aquifer.

The ${ }^{14} \mathrm{C}$ modelling results match well with $\delta^{18} \mathrm{O}$ and $\delta^{2} \mathrm{H}$ data, which show a palaeorecharge effect (Fig. 8). Prior to the Last Glacial Maximum, enriched stable isotope values can be observed and indicate warmer climatic conditions corresponding to the interstadial age (Jiráková et al., 2009). Comparison with $\delta^{18} \mathrm{O}$ and $\delta^{2} \mathrm{H}$ substantiate the radiocarbon ages. The lighter $\delta^{18} \mathrm{O}$ and $\delta^{2} \mathrm{H}$ isotopic conditions indicate groundwater recharge at a lower temperature during the late Pleistocene compared with the Holocene and confirm information provided by noble gases on this aquifer (Rudolph et al., 1983, 1984). The absence of any ages of between 17 and 24 ka BP may provide evidence for the absence of recharge during or around the glacial maximum (Darling, 2004), but it is noted that there is also a smaller number of sampling points compared to the whole aquifer area. The depletion in ${ }^{18} \mathrm{O}$ and ${ }^{2} \mathrm{H}$ is about $2 \delta$ and $10 \delta$, respectively, which is consistent with other palaeogroundwater studies in Europe (Rozanski, 1985; Huneau, 2000, etc.). 

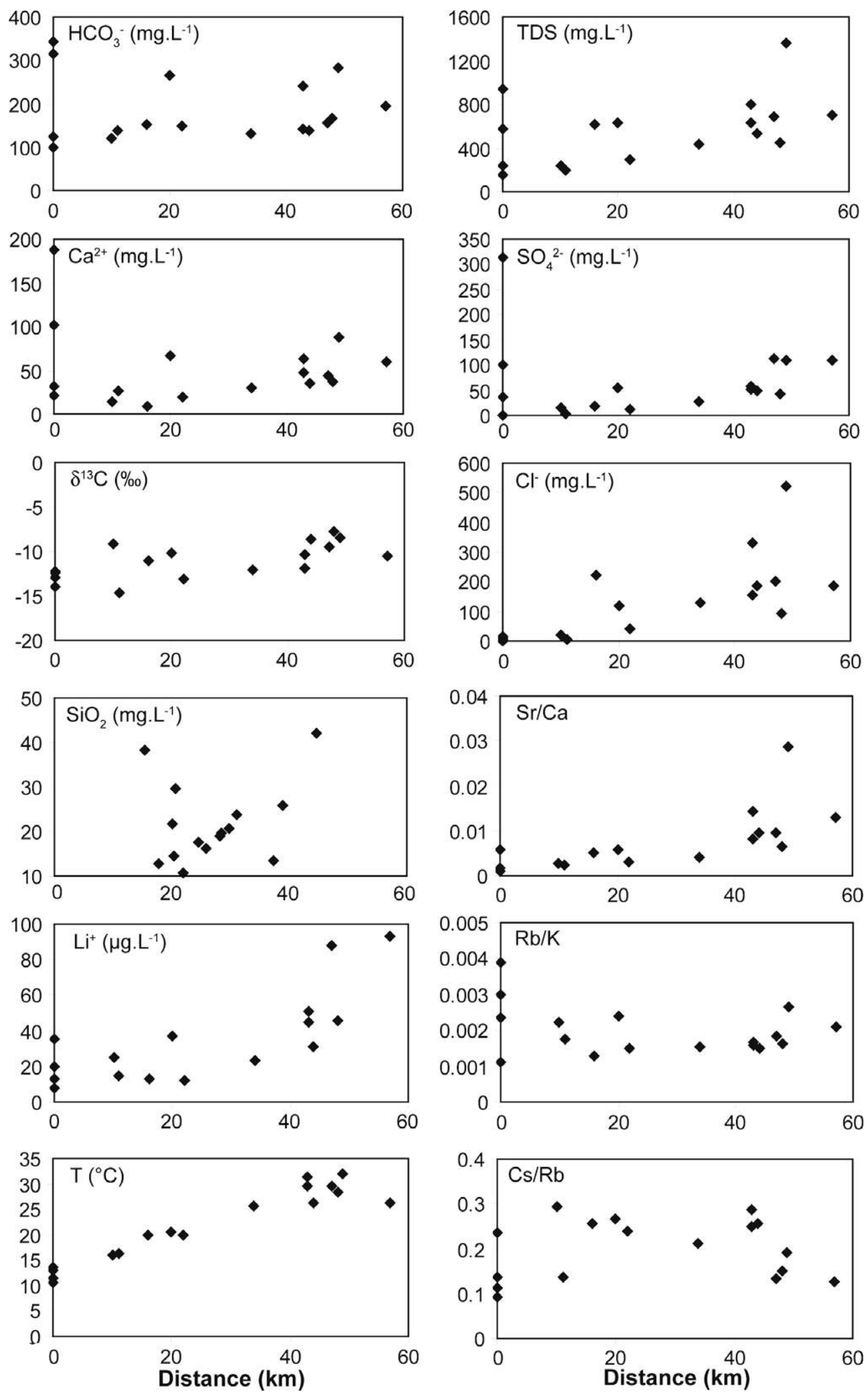

Fig. 5. Downgradient trends for $\mathrm{HCO}_{3}^{-}, \mathrm{Ca}^{2+}, \delta^{13} \mathrm{C}, \mathrm{SiO}_{2}, \mathrm{Li}^{+}, \mathrm{T}{ }^{\circ} \mathrm{C}, \mathrm{TDS}, \mathrm{SO}_{4}^{2-}, \mathrm{Cl}^{-}$and ratios $\mathrm{Sr} / \mathrm{Ca}, \mathrm{Rb} / \mathrm{K}, \mathrm{Cs} / \mathrm{Rb}$.

4.2. Groundwater characteristics from major ions and statistical information

\subsubsection{Major chemical characteristics}

Datasets for major, minor and trace elements are presented using cumulative probability plots (Shand and Edmunds, 2008) in order to consider statistical distributions and to help discriminate geological and geochemical controls on the groundwater compositions (Fig. 9). It appears that the baseline quality of the groundwater in the LTSA is represented by a wide range of concentrations mainly dominated by water-rock interactions. Moreover Fig. 9 shows that $\mathrm{Ca}^{2+}$ and $\mathrm{HCO}_{3}^{-}$are the major constituents for $40 \%$ of 


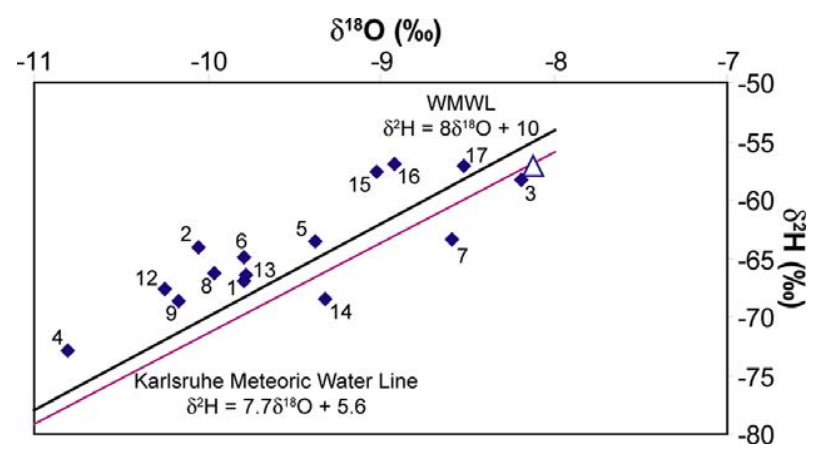

Fig. 6. $\delta^{18} \mathrm{O}$ versus $\delta^{2} \mathrm{H}$ for the LTSA. World meteoric water line (Craig, 1961) and Karlsruhe meteoric water line have been plotted (IAEA/WMO, 2006), weighted mean isotopic content of Karlsruhe precipitation is represented by a triangle.

the groundwater samples characterised by low mineralization (TDS). For the highest TDS, contributions of $\mathrm{SO}_{4}^{2-}, \mathrm{Cl}^{-}$and $\mathrm{Na}^{+}$increase; they become the major constituents in association with $\mathrm{HCO}_{3}^{-}$. This is confirmed by major element distributions shown on the Piper diagram (Fig. 10); the groundwaters in the LTSA vary from $\mathrm{Ca}-\mathrm{HCO}_{3}$ and $\mathrm{Ca}-\mathrm{Mg}-\mathrm{HCO}_{3}$ to $\mathrm{Na}-\mathrm{Cl}$ types. Kirschnaumen is the exception with a $\mathrm{Ca}-\mathrm{SO}_{4}-\mathrm{HCO}_{3}$ type.

A principal component analysis (PCA) was carried out to support the relationships between chemical and isotopic variables and distance to recharge area. The two principal axes of PCA explain $69 \%$ of the sampling variance. Axis 1 (39\%) opposes $\mathrm{Na}^{+}$, $\mathrm{Cl}^{-}, \mathrm{K}^{+}$, distance to recharge area and temperature to $\delta^{18} \mathrm{O} \%$. Axis 2 is defined by $\mathrm{Ca}^{2+}, \mathrm{SO}_{4}^{2-}, \mathrm{HCO}_{3}^{-}$and $\mathrm{Mg}^{2+}$. Two groups of water can be discriminated. Group I is characterised by the highest $\mathrm{NO}_{3}^{-}$content, which suggests a short residence time within the aquifers. Group I also has the highest $\mathrm{Ca}^{2+}, \mathrm{SO}_{4}^{2-}, \mathrm{HCO}_{3}^{-}$. The Kirschnaumen borehole is characterised by the highest value of $\mathrm{NO}_{3}^{-}$ $(14 \mathrm{mg} / \mathrm{L})$ and $\mathrm{SO}_{4}^{2-}(314 \mathrm{mg} / \mathrm{L})$ that could define an anthropogenic origin for both $\mathrm{SO}_{4}^{2-}$ and $\mathrm{NO}_{3}^{-}$. However the increase in both $\mathrm{Ca}^{2+}$ and $\mathrm{SO}_{4}^{2-}$ as well as $\mathrm{Sr}^{2+}$ (Fig. 5) could be due to gypsum dissolution with a possible downward leakage from the Middle Triassic marls and clays. Conversely, Group II shows the greatest distances to recharge area, which suggests a long residence time within the aquifer. These waters also have the highest $\mathrm{Na}^{+}$and $\mathrm{Cl}^{-}$contents that are closely associated with halite dissolution. So the groups discriminated with PCA show different chemical facies according to increasing distance to the recharge area.
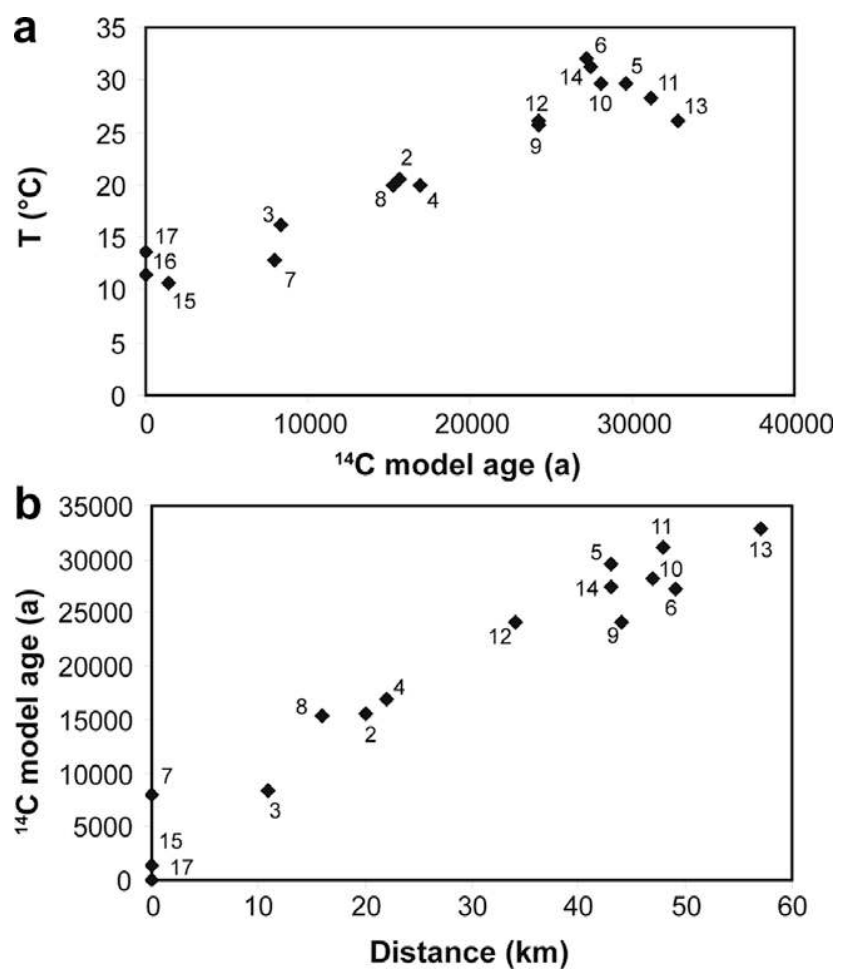

Fig. 7. (a) Temperature versus ${ }^{14} \mathrm{C}$ model age in the LTSA. (b) ${ }^{14} \mathrm{C}$ model (Fontes and Garnier, 1979) age (a) versus distance to recharge area ( $\mathrm{km})$.

\subsubsection{Evolution along the main flow direction}

According to the results obtained with the PCA, sites have been projected onto a single line following the flow direction from the recharge area in the Vosges Mountains to the Luxembourg border (Fig. 1). The well depths or rather the intervals from which the water is derived are between $120 \mathrm{~m}$ in the recharge area to over $800 \mathrm{~m}$ in the deepest western part of the study area, close to the Nancy-Metz line.

Groundwater well-head temperatures increase from around $10^{\circ} \mathrm{C}$ in the recharge area to greater than $30^{\circ} \mathrm{C}$ at depth (Fig. 3). Groundwater chemistry also evolves along a flow path as shown in Fig. 5. Shallow and intermediate depth groundwater in the south has low mineralization (TDS). At greater depth, in the northern part

Table 9

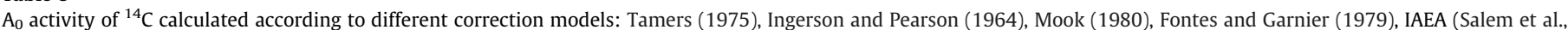
1980), Evans et al. (1979), Eichinger (1983).

\begin{tabular}{|c|c|c|c|c|c|c|c|c|}
\hline & & Tamers & Pearson & Mook & $F \& G$ & IAEA & Evans & Eichinger \\
\hline \multicolumn{9}{|c|}{ Unevolved groundwater } \\
\hline 3 & Blamont & 53.8 & 66.8 & 105.9 & 75.5 & 112.0 & 66.0 & 64.7 \\
\hline 7 & Saint-Louis & 56.3 & 63.6 & 100.7 & 69.0 & 109.9 & 63.1 & 61.2 \\
\hline 15 & Guerting & 64.6 & 56.3 & 79.4 & 56.2 & 99.4 & 55.9 & 50.4 \\
\hline 16 & Dalem & 67.2 & 56.1 & 75.5 & 56.0 & 98.1 & 55.6 & 48.8 \\
\hline 17 & Kirschnaumen & 62.9 & 58.5 & 84.1 & 58.4 & 100.3 & 57.8 & 53.8 \\
\hline \multicolumn{9}{|c|}{ Evolved groundwater } \\
\hline 2 & Saint-Clément & 55.9 & 46.5 & 73.1 & 46.2 & 75.3 & 44.8 & 42.5 \\
\hline 4 & Moussey & 51.1 & 59.5 & 96.0 & 64.7 & 96.6 & 58.2 & 57.1 \\
\hline 5 & Bathélémont & 53.1 & 46.9 & 73.9 & 46.5 & 70.7 & 44.0 & 43.4 \\
\hline 6 & Tomblaine & 56.4 & 38.5 & 61.1 & 37.5 & 57.2 & 34.9 & 32.6 \\
\hline 8 & Langatte & 50.3 & 50.5 & 84.6 & 50.7 & 82.2 & 49.0 & 48.0 \\
\hline 9 & Dieuze & 51.6 & 54.6 & 86.1 & 56.2 & 84.8 & 52.6 & 52.1 \\
\hline 10 & Puttigny & 51.6 & 42.5 & 69.9 & 42.0 & 64.1 & 39.4 & 39.1 \\
\hline 11 & Morhange & 53.1 & 35.6 & 60.4 & 34.7 & 54.3 & 32.3 & 31.1 \\
\hline 12 & Rodalbe & 51.5 & 39.7 & 67.2 & 39.1 & 61.5 & 36.9 & 36.3 \\
\hline 13 & Holacourt & 52.9 & 47.8 & 76.2 & 47.5 & 74.0 & 45.4 & 44.6 \\
\hline 14 & Hellimer & 51.4 & 54.1 & 83.6 & 55.5 & 80.8 & 51.5 & 51.7 \\
\hline
\end{tabular}



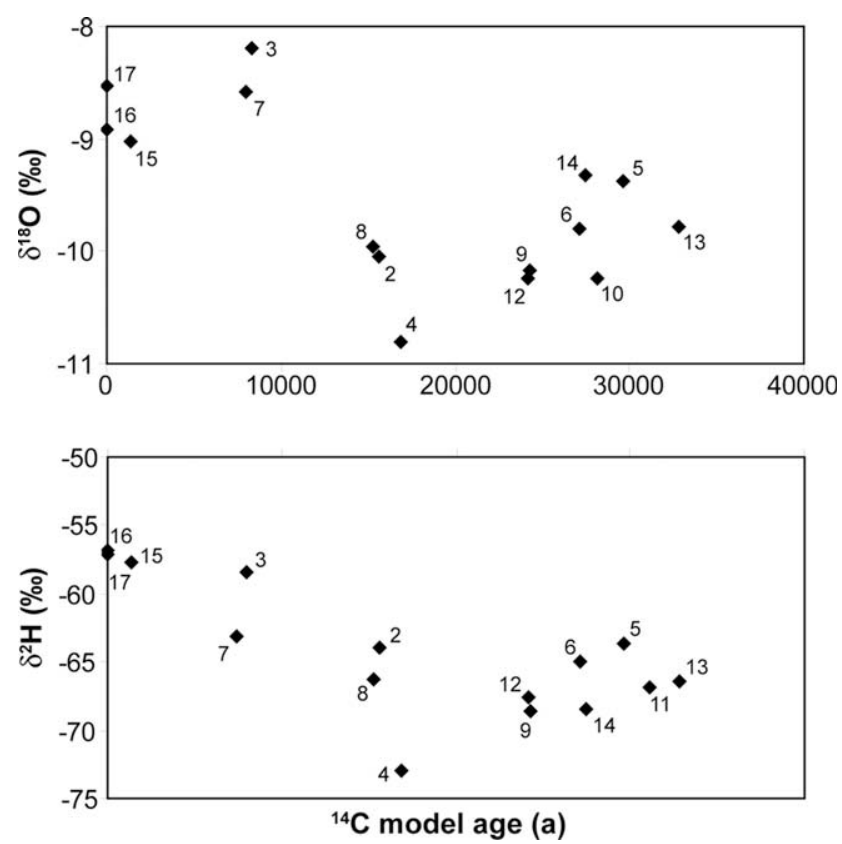

Fig. 8. Plots of $\delta^{18} \mathrm{O}$ and $\delta^{2} \mathrm{H}$ against ${ }^{14} \mathrm{C}$ model (Fontes and Garnier, 1979) age (a).

of the area, groundwater mineralization increases and as it becomes enriched in $\mathrm{Na}^{+}$and $\mathrm{Cl}^{-}$.

Chloride can be regarded as geochemically inert and its concentration and variation should be source-related: atmospheric inputs, anthropogenic inputs or mixing with formation waters or evaporites within the aquifer may give rise to changing $\mathrm{Cl}$ concentrations which should indicate significant recharge/mixing boundaries in the aquifer. Close to the outcrop area of the LTSA, $\mathrm{Cl}^{-}$concentrations represent input concentrations from atmospheric sources after allowing for evaporative concentration with values between 2.5 and $18.8 \mathrm{mg} \mathrm{L}^{-1}$ in good agreement with the results observed by Edmunds and Smedley (2000) for the East Midlands Triassic Sandstones. It must be noted that the recharge area of the LTSA is covered by the Vosges forest composed of about 70\% evergreen trees providing perennial canopy. This kind of land cover is known to collect aerosols during dry periods (Appelo and Postma, 2005) and to increase $\mathrm{Cl}$ inputs as clearly shown in Table 3 by the throughfall input compared to rainfall input.

The $\mathrm{Na}^{+}$and $\mathrm{Cl}^{-}$concentrations range from 1.6 to $302 \mathrm{mg} / \mathrm{L}$ and from 2.6 to $522 \mathrm{mg} / \mathrm{L}$, respectively (Table 5). The strong correlation between these two elements ( $R=0.98$, Fig. 3 ) suggests dissolution of halite in the confined part of the LTSA which is supported by Fig. 5. Sources include evaporite deposits, mainly composed of anhydrite and gypsum but also of halite, from the overlying formations and Permian formations that contain local deposits of halite (Fig. 2). A strong correlation exists between depth of boreholes and concentrations of $\mathrm{Cl}^{-}$and $\mathrm{Na}^{+}$(Fig. 3). Tomblaine and Hellimer, two of the deeper boreholes of the study area $(708 \mathrm{~m}$ and $800 \mathrm{~m}$, respectively, Table 4 ), have the highest concentrations in $\mathrm{Na}^{+}$ (301 mg/L and $170 \mathrm{mg} / \mathrm{L}$, respectively, Table 5) and $\mathrm{Cl}^{-}(522 \mathrm{mg} / \mathrm{L}$ and $330 \mathrm{mg} / \mathrm{L}$, respectively, Table 5) and moderate concentrations in $\mathrm{SO}_{4}^{2-}$ and $\mathrm{Ca}^{2+}$ (Table 5). Their content of $\mathrm{Cl}^{-}$and $\mathrm{Na}^{+}$seems to be influenced by waters circulating within Permian formations (Salado and Passavy, 1980).

Although relatively inert, $\mathrm{Br}^{-}$may be slightly enriched or depleted relative to its ratio to $\mathrm{Cl}^{-}$in sea water as a result of various physical or geochemical processes and the $\mathrm{Br} / \mathrm{Cl}$ ratio may be used to determine likely origins and evolution of groundwater and to constrain the interpretation of $\mathrm{Cl}^{-}$contents (Edmunds, 1996). In the case of LTSA, a strong depletion of $\mathrm{Br} / \mathrm{Cl}$ ratios below 0.001 con- firms the dissolution or addition of $\mathrm{Cl}^{-}$from evaporite sources (Table 5).

Sulphate concentrations are variable (Fig. 5), an increase from 1 to around $313 \mathrm{mg} / \mathrm{L}$ occurs from the recharge area to Luxembourg. Close to the LTSA outcrop area, the Kirschnaumen and Dalem boreholes have high $\mathrm{SO}_{4}^{2-}$ concentrations correlated with high $\mathrm{Ca}^{2+}$ (Fig. 3), indicating preferential gypsum or anhydrite dissolution. This gypsum or anhydrite dissolution could also occur along the flow line (Rodalbe, Bathélémont). This process concerns mainly shallow and intermediate depth groundwater and so seems directly related with waters circulating at the contact with overlying formations (Muschelkalk and Keuper evaporitic deposits).

The downgradient evolution of silica concentrations is shown in Fig. 5. Silica is rapidly released by water-rock interaction with silicate minerals but the upper concentrations are controlled by slower equilibration with silica polymorphs. Groundwaters are all above quartz saturation and exhibit Si concentration from about 14 to $24 \mathrm{mg} / \mathrm{L}$ quite well correlated with distance from the recharge area and thus with residence time. Calculations using PHREEQ-C (Parkhurst and Appelo, 1999) indicate that all groundwaters are clearly oversaturated with quartz and slightly undersaturated or at equilibrium with chalcedony, which is the likely main control. The good correlation with temperature indicates that silica could be used as a geothermometer.

The systematic increase of Li (Fig. 5) across the aquifer could be due to the diagenesis of clay minerals (Edmunds and Smedley, 2000). However, the high concentration $\left([\mathrm{Li}+]=600 \mu \mathrm{g} \mathrm{L}^{-1}\right)$ of Tomblaine (not shown on the graph), can be linked with the dissolution of evaporites. Rubidium/K and $\mathrm{Cs} / \mathrm{Rb}$ ratios are relatively constant along the flow path attesting to a similar pathway downgradient for the three elements suggesting an increase of groundwater residence time within the aquifer. Potassium concentrations are dominated by reactions between groundwater and K-bearing mineral phases such as K-feldspar and clays. Increases of $\mathrm{Rb}$ and $\mathrm{Cs}$ are considered to be linked primarily to the alteration of the $\mathrm{K}$-feldspar with the trace cations being retained in the groundwater.

Sources of Ba also include K-rich minerals such as K-feldspar, biotite and barite. Solubility is controlled by saturation with respect to barite. Barium concentrations in the LTSA remain low and are at or close to saturation throughout the aquifer (Table 8), the smooth increase along the flow line is only a reflection of the adjustment of the equilibrium to the concentrations of $\mathrm{SO}_{4}^{2-}$.

The reactions of carbonate minerals may be followed by means of $\mathrm{pH}, \mathrm{HCO}_{3}^{-}, \mathrm{Ca}^{2+}$ and $\mathrm{Mg}^{2+}$ as well as some trace elements $\left(\mathrm{Sr}^{2+}\right)$ and the stable isotope ratio $\delta^{13} \mathrm{C}$. Calcium, $\mathrm{Mg}^{2+}$ and $\mathrm{HCO}_{3}^{-}$concentrations are variable (Fig. 5 , Table 5 ). The positive correlation between $\mathrm{HCO}_{3}^{-}$and $\mathrm{Ca}^{2+}(R=0.88)$ indicates the occurrence of calcite dissolution in the aquifer. So the dissolution of calcite and dolomite provides the initial dominant control. Most groundwaters are at or above calcite and dolomite saturation (Table 8). This may be an effect of the well-head $\mathrm{pH}$ measurements not reflecting an equilibrium condition; a decrease of $0.5 \mathrm{pH}$ units balancing a loss of $\mathrm{CO}_{2}$ would bring values closer to saturation. The dissolution of gypsum in these waters should also tend to maintain saturation or over-saturation with respect to carbonate minerals. The $\mathrm{Mg} / \mathrm{Ca}$ ratio is around 0.5 over much of the aquifer with an equilibrium control slightly lower than that expected if both calcite and dolomite are the controls (0.8: Smedley and Edmunds, 2002). The $\delta^{13} \mathrm{C}$ evolution confirms these observations as $\delta^{13} \mathrm{C}$ becomes more positive along the flow direction as the calcite reaction is superseded by that of dolomite (Kloppmann et al., 1998; Edmunds and Smedley, 2000). Strontium is typically derived from water-rock interactions mainly from Ca-rich minerals such as calcite, Ca-rich feldspars or gypsum/anhydrite. The increase along the flow line, as $\mathrm{Ca}^{2+}$ (Hem, 1985), is due initially to the incongruent reactions of 

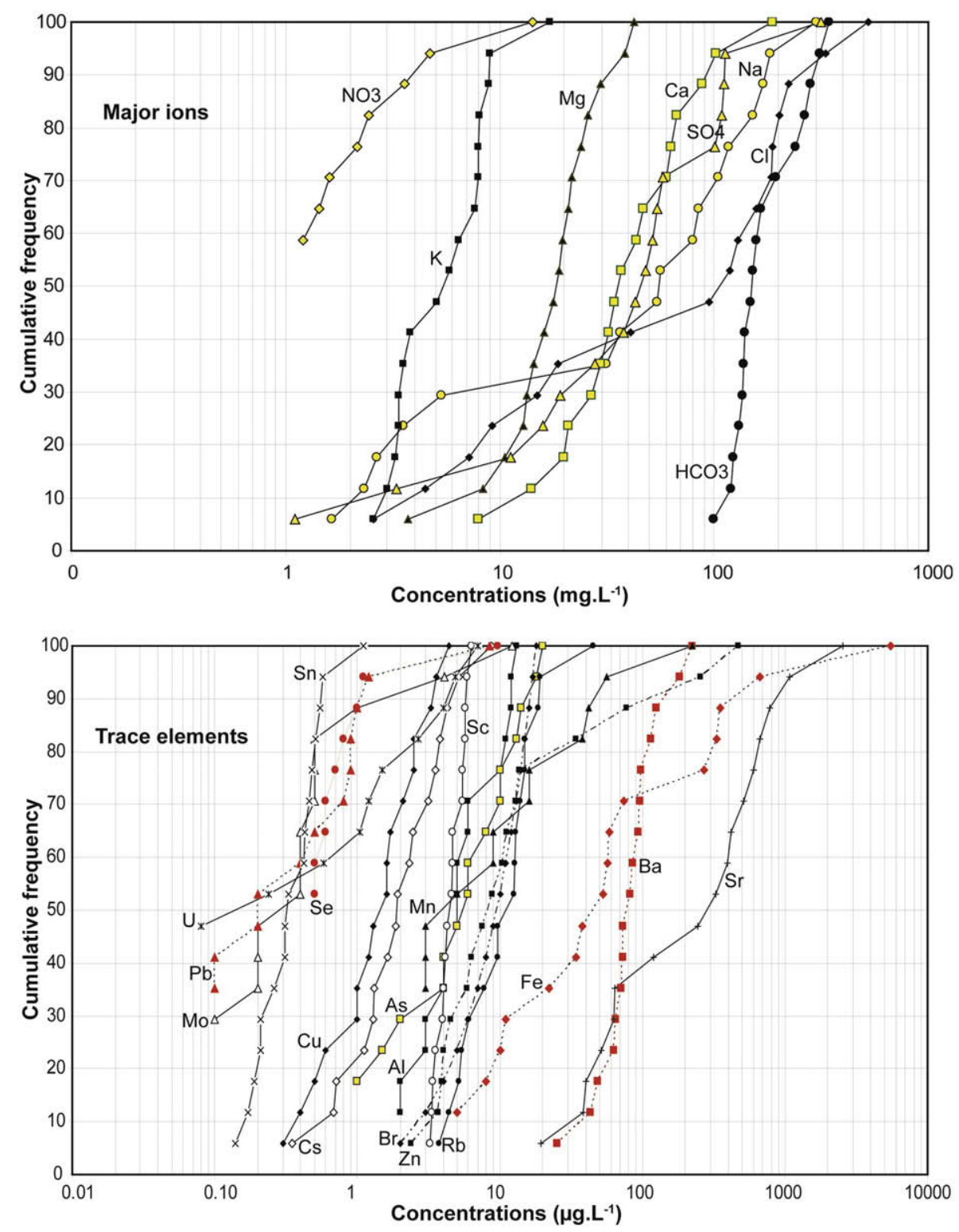

Fig. 9. Cumulative probability plots for major ions and trace elements in the LTSA.

carbonate minerals, but then at depth possibly some of the $\mathrm{Sr}^{2+}$ may be added by the dissolution of anhydrite or gypsum.

Profiles of major chemical markers of redox processes $\left(\mathrm{Eh}, \mathrm{NO}_{3}^{-}\right.$, $\mathrm{Fe}, \mathrm{U}$ ) in the LTSA are put together in Fig. 4. Evolution of these redox sensitive parameters does not show any clear redox boundary but a tendency is however observed. The global evolution of $\mathrm{NO}_{3}^{-}$ follows Eh variations: $\mathrm{NO}_{3}^{-}$concentrations decreases from the outcrop area to below detection $<0.1 \mathrm{mg} \mathrm{L}^{-1}$ for the deepest boreholes. A few points show little $\mathrm{NO}_{3}^{-}$concentrations probably due to mixing with middle and upper Triassic levels thanks to low quality well casing (Kirschnaumen). Concentrations $<5 \mathrm{mg} \mathrm{L}^{-1}$ may reflect both the development of redox conditions able to contribute to the lowering of $\mathrm{NO}_{3}^{-}$concentrations and the influence of vegetation able to using up the $\mathrm{N}$ in the recharge area. The anthropogenic origin of $\mathrm{NO}_{3}^{-}$is not then demonstrated because the throughfall content in the recharge area is slightly less than $5 \mathrm{mg} \mathrm{L}^{-1}$ (Table 3). Dissolved $\mathrm{P}$ concentrations in groundwater, data not shown, are closely related to $\mathrm{NO}_{3}^{-}$concentrations; anthropogenic sources in- clude inorganic and organic fertilisers, water treatment works and farmyard slurry.

Iron and Mn concentrations are low (Table 6) and originate from primary minerals or secondary oxides and oxy-hydroxides present in most rock types. Primary sources of Fe and Mn include carbonates and silicates. Both Fe and Mn are redox sensitive elements in groundwater, being soluble in their reduced form but forming insoluble oxy-hydroxides under oxidising conditions. The Guerting sample with high $\mathrm{Fe}$ concentration, high $\mathrm{SO}_{4}$ and low Ca (Tables 5 and 6 ) shows that pyrite oxidation could be occurring. The relatively low $\mathrm{pH}$ strengthens this hypothesis.

Uranium shows a residence-time-dependant increase in the aerobic ground water, reaching $7 \mu \mathrm{g} \mathrm{L}^{-1}$ (Table 6). In the deeper part of aquifer, about $40 \mathrm{~km}$ from the recharge area, there is a residence time control over the increase and downgradient progress. Concentrations of $U$ are very low due to lower solubility of uranous minerals and to the adsorption of ions onto Fe oxides (Smedley and Edmunds, 2002). This evolution suggests the existence of a redox boundary at about $40 \mathrm{~km}$ from the recharge area that is clearly 
Table 10

Groundwater age calculation.

\begin{tabular}{|c|c|c|c|c|c|c|c|c|c|c|c|c|c|c|c|c|c|}
\hline & & Tamers & \pm & Pearson & \pm & Mook & \pm & $F \& G$ & \pm & IAEA & \pm & Evans & \pm & Eichinger & \pm & $\mathrm{nc}$ & \pm \\
\hline \multicolumn{18}{|c|}{ Unevolved groundwater } \\
\hline 3 & Blamont & 5500 & 230 & 7300 & 220 & 11,100 & 190 & 8300 & 210 & 11,600 & 190 & 7200 & 220 & 7000 & 220 & 10,600 & 200 \\
\hline 7 & Saint-Louis & 6300 & 230 & 7300 & 230 & 11,100 & 200 & 8000 & 220 & 11,800 & 200 & 7200 & 230 & 6900 & 230 & 11,000 & 200 \\
\hline 15 & Guerting & 2600 & 220 & 1400 & 230 & 4200 & 210 & 1400 & 230 & 6100 & 200 & 1400 & 240 & 500 & 240 & 6200 & 200 \\
\hline 16 & Dalem & Modern & 140 & Mod. & 150 & Mod. & 130 & Mod. & 150 & 1700 & 120 & Mod. & 150 & Mod. & 160 & 1900 & 120 \\
\hline 17 & Kirschnaumen & 100 & 150 & Mod. & 150 & 2500 & 130 & Mod. & 150 & 4000 & 130 & Mod. & 160 & Mod. & 160 & 4000 & 130 \\
\hline \multicolumn{18}{|c|}{ Evolved groundwater } \\
\hline 2 & Saint-Clément & 17,200 & 430 & 15,700 & 450 & 19,400 & 420 & 15,600 & 450 & 19,700 & 410 & 15,300 & 450 & 14,900 & 460 & 22,000 & 400 \\
\hline 4 & Moussey & 15,000 & 970 & 16,200 & 1000 & 20,100 & 930 & 16,900 & 950 & 20,200 & 1000 & 16,000 & 960 & 15,900 & 960 & 20,500 & 930 \\
\hline 5 & Bathélémont & 30,700 & 1990 & 29,700 & 2000 & 33,400 & 1970 & 29,600 & 2000 & 33,000 & 1970 & 29,100 & 2010 & 29,000 & 2003 & 35,900 & 1950 \\
\hline 6 & Tomblaine & 30,600 & 1260 & 27,400 & 1290 & 31,200 & 1250 & 27,200 & 1300 & 30,700 & 1260 & 26,600 & 1300 & 26,000 & 1310 & 35,300 & 1230 \\
\hline 8 & Langatte & 15,300 & 390 & 15,200 & 400 & 19,500 & 360 & 15,300 & 400 & 19,300 & 360 & 15,000 & 400 & 14,800 & 400 & 20,900 & 360 \\
\hline 9 & Dieuze & 23,600 & 910 & 24,000 & 910 & 27,800 & 880 & 24,200 & 900 & 27,600 & 880 & 23,700 & 910 & 23,600 & 910 & 29,000 & 870 \\
\hline 10 & Puttigny & 29,900 & 1260 & 28,200 & 1280 & 32,300 & 1240 & 28,100 & 1280 & 31,600 & 1250 & 27,600 & 1290 & 27,500 & 1290 & 35,300 & 1230 \\
\hline 11 & Morhange & 34,700 & 2150 & 31,400 & 2190 & 35,800 & 2140 & 31,200 & 2190 & 34,900 & 2150 & 30,600 & 2200 & 30,300 & 2200 & 39,900 & 2110 \\
\hline 12 & Rodalbe & 26,500 & 1260 & 24,300 & 1290 & 28,700 & 1250 & 24,200 & 1290 & 27,900 & 1250 & 23,700 & 1300 & 23,600 & 1300 & 31,900 & 1230 \\
\hline 13 & Holacourt & 33,700 & 2840 & 32,900 & 2850 & 36,700 & 2810 & 32,800 & 2850 & 36,500 & 2820 & 32,400 & 2850 & 32,300 & 2850 & 38,900 & 2800 \\
\hline 14 & Hellimer & 26,900 & 910 & 27,300 & 910 & 30,900 & 880 & 27,500 & 910 & 30,600 & 880 & 26,900 & 1000 & 26,900 & 910 & 32,300 & 870 \\
\hline
\end{tabular}

nc: Not corrected.

Mod.: Modern recharge.

Uncertainty: $|\Delta t|=8267 \cdot\left(\left|\Delta A_{0} / A_{0}\right|+\left|\Delta A_{t} / A_{t}\right|\right)$ year.

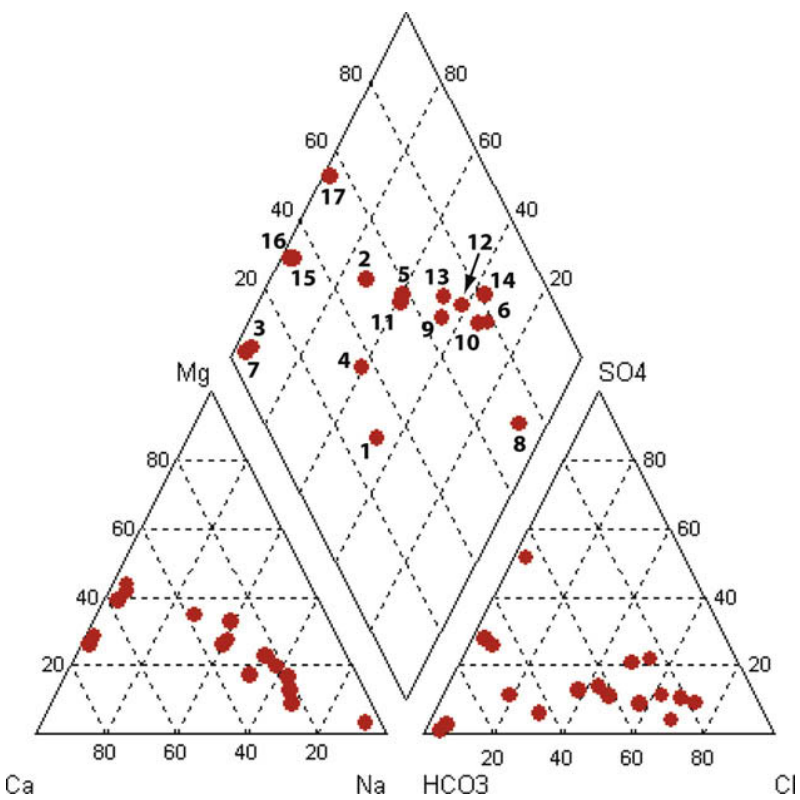

Fig. 10. Piper diagram for the selected boreholes of the LTSA. Numbered sample sites refer to sample numbers in Tables.

translated in the evolution of $U$ exactly as it is in the case of the East Middlands Triassic aquifer (Smedley and Edmunds, 2002). According to this, boreholes Bathélémont, Tomblaine, Puttigny, Morhange, Rodalbe, Holacourt and Hellimer would show reducing conditions.

Arsenic (Table 6) does not show any significant evolution from the recharge area. Concentrations are in excess of the European Water Standards ( $>10 \mu \mathrm{g} / \mathrm{L}$ ) in some places (Tomblaine, Langatte, Hellimer). These concentrations do not seem to be due to waterrock interaction processes within the LTSA; mixing with deeper waters enriched in As may be suggested since many boreholes reach the granitic basement where the Permian beds are missing. It must be noted that high concentrations of As are not correlated with high concentrations of Fe or $\mathrm{Mn}$ and that no relationship is observed with residence time.

\section{Groundwater evolution since the 1970s}

\subsection{Evolution in groundwater quantity from 1970 to present and prospective}

In 2000, the balance between recharge processes and abstraction for the LTSA was in equilibrium. That was not the situation from 1970 to 1980 when a shortage of $19 \mathrm{Mm}^{3} \mathrm{a}^{-1}$ was recorded. Between 1977 and 2000, the total volume of groundwater abstracted from the LTSA has decreased by about 30\%. In 2013, after the complete cessation of coal mine pumping, this volume would reach $46 \%$ (Vaute, 2004). The evolution of the volume abstracted with time is shown on Fig. 11. The total volume of abstracted groundwater is greater than the natural recharge rate of the aquifer as substantiated by the regular decrease of potentiometric levels, of about $0.5 \mathrm{~m} / \mathrm{a}$ on average since 1950 in the most affected areas. As a consequence, the lowering of the water table has been estimated as follows: $7-8 \mathrm{~m}$ in 10 a close to the Sarre region, 18$20 \mathrm{~m}$ in 30 a close to Vittel, more than $40 \mathrm{~m}$ in 75 a close to Nancy, 50-150 m close to the German border (Fig. 1). The general groundwater flow varied from a north-eastward direction in 1979 (Blavoux and Olive, 1981) to a more uniform northward direction in 1997 (BURGEAP, 1998). Such a decrease of the water table is responsible for a strong modification of hydraulic gradients and may entail strong modifications in the origin and age of groundwater (Huneau et al., 2001).

\subsection{Evolution of the residence time indicators from 1979 to 2001}

Nine out of the 17 sampled boreholes (Hellimer, Tomblaine, Puttigny, Dieuze, Langatte, Moussey, Saint-Clément, Gélacourt, Morhange) were previously sampled by Blavoux and Olive in 1979 (Blavoux and Olive, 1981) and give the opportunity to compare the evolution in chemical and isotopic content of LTSA groundwater (Table 11).

Stable isotopes of the water molecule and particularly ${ }^{18} \mathrm{O}$ content show significant evolution between 1979 and 2001 in places where strong evolution of radiocarbon content is observed. This evolution corresponds to decreasing values that can be explained by the participation of more ${ }^{18} \mathrm{O}$ depleted waters originating from palaeogroundwaters (Pleistocene origin) confined within the LTSA. This evolution can be observed at Puttigny, Dieuze and Moussey. 


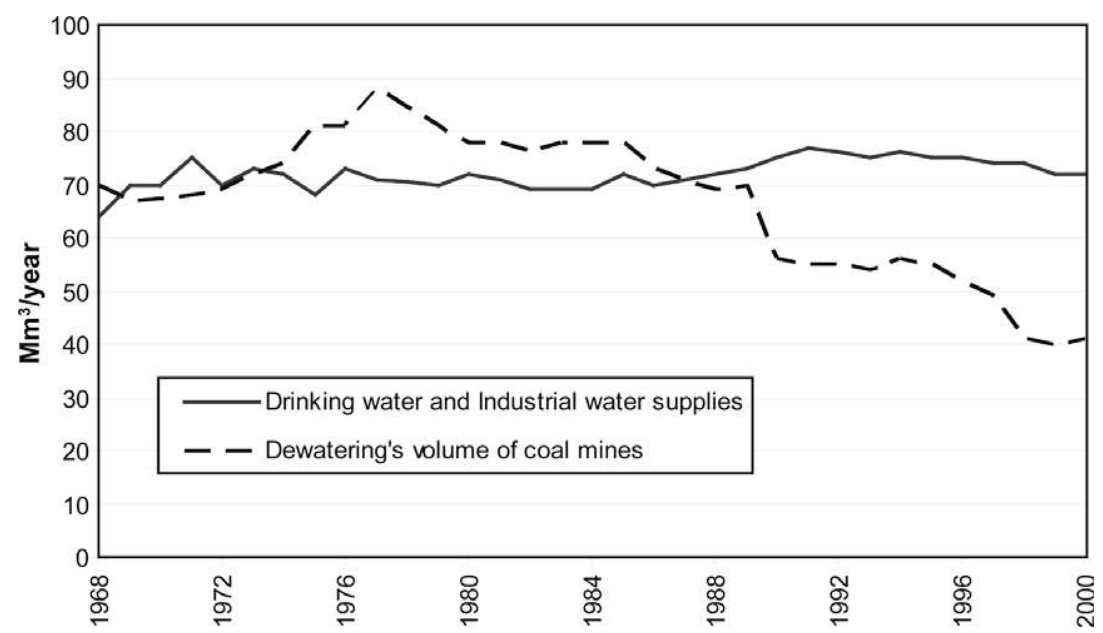

Fig. 11. Evolution of drinking water and industrial water supplies and dewatering volumes of coal mines since 1968 (after Vaute, 2004 ).

Table 11

Evolution of selected parameters between 1979 and 2001 field campaigns.

\begin{tabular}{|c|c|c|c|c|c|c|c|c|c|c|c|}
\hline \multirow[t]{2}{*}{ Well ID } & \multirow[t]{2}{*}{ Location } & \multicolumn{2}{|c|}{$\delta^{18} \mathrm{O}(\% 0)$} & \multicolumn{2}{|c|}{$\underline{\mathrm{Cl}^{-}(\mathrm{mg} / \mathrm{L})}$} & \multicolumn{2}{|c|}{$\mathrm{Na}^{+}(\mathrm{mg} / \mathrm{L})$} & \multicolumn{2}{|c|}{$\mathrm{NO}_{3}^{-}(\mathrm{mg} / \mathrm{L})$} & \multicolumn{2}{|c|}{$\mathrm{a}^{14} \mathrm{C}(\mathrm{pmc})$} \\
\hline & & 1978 & 2001 & 1978 & 2001 & 1978 & 2001 & 1978 & 2001 & 1978 & 2001 \\
\hline 4 & Hellimer & -10.0 & -9.3 & 313.8 & 330.0 & 179.0 & 170.1 & 0 & 2.45 & 3.9 & 2.0 \\
\hline 6 & Morhange & -10.0 & nd & 91.0 & 95.2 & 18.1 & 54.3 & 0 & 0 & 15.2 & 0.8 \\
\hline 8 & Puttigny & -9.9 & -10.2 & 193.5 & 201.2 & 145.0 & 151.6 & 0 & 1.21 & 25.4 & 1.4 \\
\hline 9 & Dieuze & -9.9 & -10.2 & 140.2 & 128.6 & 82.0 & 80.2 & 0 & 0 & 17.9 & 3.0 \\
\hline 10 & Langatte & -10.0 & -10.0 & 331.3 & 223.6 & 264.0 & 184.1 & 0 & 1.6 & 15.1 & 8.0 \\
\hline 12 & Moussey & -10.4 & -10.8 & 57.2 & 40.8 & 31.5 & 31.6 & 0 & 1.4 & 42.4 & 8.4 \\
\hline 13 & Tomblaine & -9.8 & -9.8 & 305.6 & 522.0 & 232.0 & 301.7 & 0 & 0 & 22.8 & 1.4 \\
\hline 14 & Saint-Clément & -9.8 & -10.1 & 112.5 & 118.0 & 47.5 & 58.5 & 0 & 4.7 & 6.9 & 7.0 \\
\hline 15 & Gélacourt & -9.8 & -9.8 & 33.0 & 18.8 & 20.2 & 36.7 & 0 & 3.6 & 11 & nd \\
\hline
\end{tabular}

Theoretically a similar evolution should be observed in the ${ }^{2} \mathrm{H}$ content. However, $\delta^{2} \mathrm{H}$ results are more difficult to interpret and this indicator does not seem to be suitable for such a comparison. It must also be pointed out that the method used to evaluate the concentrations in ${ }^{2} \mathrm{H}$ in 1979 and 2001 are not the same and could lead to some small differences of about $2 \delta$ maximum.

Eight out of the nine boreholes involved in the survey show decreasing radiocarbon content of the TDIC (Table 11) which is the translation of a longer residence time of groundwater within the aquifer probably meaning that older groundwater has moved upgradient under the influence of over-abstraction of the aquifer. This evolution is particularly strong for Morhange, Moussey, Langatte, Dieuze, Puttigny and Tomblaine with a lowering of the radiocarbon activity of about 7-34 pmc. A decrease of about 2 pmc is observed at Hellimer. The borehole of Saint-Clément is the only one in the survey to show stable radiocarbon content from 1979 to 2001. All the boreholes from the central part of the aquifer tend to show strong radiocarbon content evolution in contrast with the boreholes from the unconfined aquifer and from the coalfield of the north of the region.

No clear tendency between potentiometric level evolution and evolution of radiocarbon content of groundwater is found between 1979 and 2001 (Fig. 12). For Morhange, Dieuze, Tomblaine, Puttigny and Moussey, the large decrease in groundwater level, that can reach more than $35 \mathrm{~m}$, is accompanied by significant evolution in groundwater ${ }^{14} \mathrm{C}$ activity of about $12-34 \mathrm{pmc}$. This illustrates the participation of old deep confined groundwaters to the flow, enhanced by the lowering of the water table. In other words, the higher the pumping rate, the more the abstraction of old groundwater is encouraged. It is evidence of a progressive decrease in the resource volume. In other sectors (Rodhalbe, Holacourt and

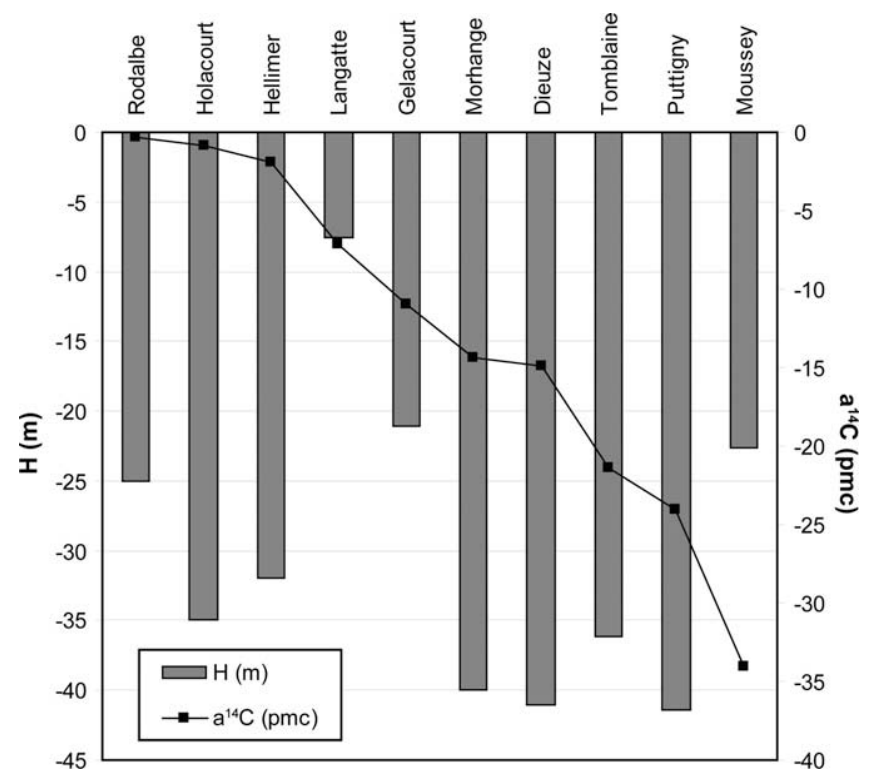

Fig. 12. Comparison between groundwater potentiometric $(H)$ surface evolution (net drawdown in $\mathrm{m}$ ) and ${ }^{14} \mathrm{C}$ content (decrease in pmc).

Hellimer) the strong lowering of the water table can reach 25$35 \mathrm{~m}$ and is not accompanied by a strong evolution in groundwater ${ }^{14} \mathrm{C}$ activity (slight decrease of 3 pmc maximum). This may reflect more stable conditions of flow within the aquifer, with a better productivity of the aquifer and good recharge conditions. The situ- 
ation of Langatte borehole is intermediate, with a small decrease of potentiometric level (about $7 \mathrm{~m}$ ) and a decrease in radiocarbon content of about $7 \mathrm{pmc}$. Anisotropy of the hydraulic parameters of the reservoir could entail bad conditions of groundwater flow around the borehole or a poor connection of this sector to the rest of the confined aquifer.

In terms of water composition, the baseline is confirmed with a variation from $\mathrm{Ca}-\mathrm{HCO}_{3}$ and $\mathrm{Ca}-\mathrm{Mg}-\mathrm{HCO}_{3}$ to $\mathrm{Na}-\mathrm{Cl}$ types. Variations in the natural chemistry of the two periods follow the same trend: the main control on the baseline quality is the geochemistry of the LTSA and downgradient evolution of chemical parameters is observed with increasing residence time. However concentrations of specific chemical parameters have evolved between 1979 and 2001 (Table 11). An increase in components associated with the dissolution of evaporites $\left(\mathrm{Na}^{+}\right.$and $\left.\mathrm{Cl}^{-}\right)$is evident (cf. Section 4.2). This phenomenon appears to have been accentuated in areas of high pumping, where the drawdown is important, close to Mohrange, Saint-Clément, Puttigny, Tomblaine and could be explained by an increase in the residence time. A few places (Dieuze, Langatte, Moussey) show relative stability of these major indicators.

Very low $\mathrm{NO}_{3}^{-}$concentrations are found in a few cases at boreholes where previously it was undetected. Thus Hellimer, Puttigny, Langatte, Moussey, Saint-Clément, Gélacourt show $\mathrm{NO}_{3}^{-}$concentrations from 1.2 to $4.7 \mathrm{mg} / \mathrm{L}$. Limited mixing between deep groundwater and surface waters is thus suspected in many places and could potentially represent a threat for the long term quality of groundwater.

Only one borehole (Gélacourt) displays a global decrease in dissolved content $\left(\mathrm{HCO}_{3}^{-}, \mathrm{SO}_{4}^{2-}, \mathrm{Cl}^{-}, \mathrm{Ca}^{2+}, \mathrm{Mg}^{2+}, \mathrm{K}^{+}\right)$. This could reflect the influence of strong mixing between deep groundwater and superficial waters characterised by low mineralization. As the concentration of $\mathrm{NO}_{3}^{-}$measured in this point is low, the mixing implies sub-surface waters instead of surface waters. The poor condition of the well casing may account for the infiltration of these sub-surface waters towards the deeper parts of the borehole and the screen.

\section{Conclusions}

The Triassic Sandstone Aquifer of Lorraine represents a huge reservoir, mostly confined, overlying Permian formations and locally Carboniferous and crystalline rocks. Baseline quality of the groundwater is represented by a wide range of concentration, mainly dominated by water-rock interaction. Based both on chemistry and isotopes, two groups varying from $\mathrm{Ca}-\mathrm{HCO}_{3}$ and $\mathrm{Ca}-\mathrm{Mg}-$ $\mathrm{HCO}_{3}$ to $\mathrm{Na}-\mathrm{Cl}$ types and from Holocene to late Pleistocene age, are clearly identified, according to depth and distance to recharge areas. Along the flow path, from unconfined to confined aquifer, an increase in most of the chemical parameters is observed (Ca, $\mathrm{K}, \mathrm{Sr}, \mathrm{Li}, \mathrm{Rb}, \mathrm{Cs}, \ldots$... This general trend is correlated with the evolution of groundwater residence time and is very close to the conceptual model developed for the East Midlands Aquifer, UK, which shows similar geological and hydrogeological patterns compared to the LTSA. However some differences occur. Thus, concentration of several ions, namely $\mathrm{Na}^{+}$and $\mathrm{Cl}^{-}$(and locally $\mathrm{SO}_{4}^{2-}$ ), increase downgradient as a result of dissolution of evaporites, related to water circulating along overlying or basement formations, or by mixing with slowly moving Permian waters. Moreover, young groundwater in the unconfined area of the East Midlands Aquifer has suffered from the effects of pollution, while water farther downdip predates pollution inputs (Smedley and Edmunds, 2002). In the LTSA, only limited contamination is noted for $\mathrm{NO}_{3}^{-}$ with values varying from 1.2 to $14.3 \mathrm{mg} \mathrm{L}^{-1}$.

Groundwater evolution since the 1970s has created a strong lowering of the water table in some places, especially in the con- fined section of the aquifer, which is accompanied by a significant evolution in groundwater age. The major difference in terms of baseline evolution is observed on $\mathrm{Cl}^{-}$and $\mathrm{Na}^{+}$concentrations, which tend to increase in the LTSA. This evolution can reach and even exceed the upper limit of the drinking water standards for the two latter parameters close to the town of Nancy (increase of $216 \mathrm{mg} \mathrm{L}^{-1}$ in $\mathrm{Cl}^{-}$and $70 \mathrm{mg} \mathrm{L}^{-1}$ in $\mathrm{Na}^{+}$). From the contaminant point of view, the occurrence of increasing $\mathrm{NO}_{3}^{-}$should be mentioned in the unconfined part of the aquifer. Even if the concentrations are very low, $\mathrm{NO}_{3}^{-}$contamination should be closely monitored. Thus, since the aerobic sections are extensive, $\mathrm{NO}_{3}^{-}$ could provide information on progress of any contamination.

The over-exploitation of the aquifer has led to the design of a new management tool, which includes the creation of an accurate database of all boreholes tapping the LTSA, including the description of the well characteristics, the history of the potentiometric head and main hydrogeochemical information. A transient mathematical model of groundwater flow has been set up and updated in 2004 (Vaute, 2004), based on hydrogeological data of 2000. Considering application of regulations, different scenarios provide a basis for estimating the recovery of the equilibrium between recharge and pumping.

The Water Framework Directive (2000/60/EC) set out requirements for the European Commission to propose further laws to protect against water pollution. A 'daughter directive' aimed at protecting groundwater has recently been adopted at European level. The Water Framework Directive sets objectives for groundwater quality, including an objective to meet "good chemical status" by 2015 , an objective on pollution trends, and an objective to prevent or limit the input of pollutants to groundwater. Clarification of the objectives, however, is left to the daughter directive. A groundwater directive was proposed by the European Commission in September 2003. It focused on the objectives mentioned above but required further development to ensure that it was practical, effective, risk-based and proportionate. Co-decision on the text for the new directive was reached in October 2006 and the directive was adopted on 12 December 2006 (2006/118/EC). Member States have until January 2009 to bring into force laws, regulations and administrative provisions to implement the new Directive.

In this text, the obligation to member states to develop monitoring tools to identify "significant and sustained upward trend" is clearly expressed in Article 5. Identification of any statistically and environmentally significant increase of concentration of pollutant, group of pollutants or indicator of pollution in groundwater for which trend reversal is identified as being necessary in accordance with Article 5. The results of the present study show that some chemical or isotopic measurements can be of benefit in such monitoring programmes. Once the overall geochemistry of the aquifer is understood, only a few key elements, namely $\mathrm{Na}^{+}$, $\mathrm{SO}_{4}^{2-}, \mathrm{Cl}^{-},{ }^{18} \mathrm{O}$, indicators of disequilibrium with increasing or decreasing proportion of overlying or deep water, require to be measured.

\section{References}

Appelo, C.A.J., Postma, D., 2005. Geochemistry, Groundwater and Pollution, second ed. Balkema Publishers, Leiden.

Blavoux, B., Olive, P., 1981. Radiocarbon dating of groundwater of the aquifer confined in the lower Triassic sandstones of the Lorraine region, France. J. Hydrol. 54, 167-183.

BURGEAP, 1998. Réalisation d'une carte piézométrique de la nappe des grès vosgiens en Lorraine (octobre 1997). Technical report 22126 RM.

Celle-Jeanton, H., Travi, Y., Loÿe-Pilot, M.D., Huneau, F., Bertrand, G., 2009 Rainwater chemistry at a Mediterranean inland station (Avignon, France): local contribution versus long range supply. Atmos. Res. 91, 118-126. doi:10.1016/j.atmosres.2008.06.003.

Craig, H., 1961. Isotopic variations in meteoric waters. Science 133, 1702-1703.

Darling, W.G., 2004. Hydrological factors in the interpretation of stable isotopic proxy data present and past: a European perspective. Quatern. Sci. Rev. 23, 743770. 
Darling, W.G., Edmunds, W.M., Smedley, P.L., 1997. Isotopic evidence for palaeowaters in the British Isles. Appl. Geochem. 12, 813-829.

Dever, L., 1985. Approches chimiques et isotopiques des interactions fluides matrice en zone non saturée carbonatée. Thesis, Paris XI, Paris.

Edmunds, W.M., 1996. Bromine geochemistry of British groundwaters. Mineral. Mag. 60, 275-284.

Edmunds, W.M., Shand, P. (Eds.), 2008. Natural Groundwater Quality. Blackwell Publishing, Oxford.

Edmunds, W.M., Smedley, P.L., 2000. Residence time indicators in groundwater: the East Midlands Triassic sandstone aquifer. Appl. Geochem. 15, 737-752.

Edmunds, W.M., Bath, A.H., Miles, D.L., 1982. Hydrochemical evolution of the East Midlands Triassic sandstone aquifer, England. Geochim. Cosmochim. Acta 46, 2069-2081.

Edmunds, W.M., Guendouz, A.H., Mamou, A., Moulla, A., Shand, P., Zouari, K., 2003. Groundwater evolution in the Continental Intercalaire aquifer of southern Algeria and Tunisia: trace element and isotopic indicators. Appl. Geochem. 18, 805-822.

Eichinger, L., 1983. A contribution to the interpretation of ${ }^{14} \mathrm{C}$ groundwater ages considering the example of a partially confined sandstone aquifer. In: Stuvier, M., Kra, R.S. (Eds.), Proc. 11th Internat. 14C Conf. Radiocarbon 25, 347356.

Eichinger, L., 1987. Isotopic and geochemical studies investigating the genesis of carbon dioxide content in young ground water resources development. IAEAsm-299/43, International Atomic Energy Agency, Vienna, pp. 87-103.

El-Ghali, M.A.K., Morad, S., Mansurbeg, H., Caja, M.A., Sirat, M., Ogle, N., 2009 Diagenetic alterations related to marine transgression and regression in fluvial and shallow marine sandstones of the Triassic Buntsandstein and Keuper sequence, the Paris Basin, France. Mar. Petrol. Geol. 26, 289-309.

Elliot, T., Andrews, J.N., Edmunds, W.M., 1999. Hydrochemical trends, palaeorecharge and groundwater ages in the fissured Chalk aquifer of the London and Berkshire basins, UK. Appl. Geochem. 14, 333-363.

Evans, G.V., Otlet, R.L., Downing, A., Monkhouse, R.A., Rae, G., 1979. Some problems in the interpretation of isotope measurements in United Kingdom aquifers. In: Isotope Hydrology II. IAEA, Vienna, pp. 679-708.

Fleyfel, M., Bakalowicz, M., 1980. Etude géochimique et isotopique du carbone minéral dans un aquifère karstique. Coll. Soc. Géol., 231-245.

Fontes, J.C., Garnier, J.M., 1979. Determination of the initial activity of the total dissolved carbon. A review of the existing models and a new approach. Water Resour. Res. 12, 399-413.

Gat, J.R., 1971. Comments on the stable isotope method in the regional groundwater investigation. Water Resour. Res. 7, 980-993.

Gossel, W., Ebraheem, A.M., Wycisk, P., 2004. A very large scale GIS based groundwater flow model for the Nubian sandstone aquifer in Eastern Sahara (Egypt, northern Sudan and eastern Libya). Hydrogeol. J. 12, 698-713.

Hem, J.D., 1985. Study and interpretation of the chemical characteristics of natural water. US Geol. Surv. Water Supply Paper, pp. 22-54.

Huneau, F., 2000. Fonctionnement hydrogéologique et archives paléoclimatiques d'un aquifère profond méditerranéen. Etude géochimique et isotopique du bassin miocène de Valréas (Sud-Est de la France). PhD Thesis, Avignon Univ. oai:tel.archives-ouvertes.fr:tel-00323650_v1.

Huneau, F., Blavoux, B., Bellion, Y., 2001. Differences between hydraulic and radiometric velocities of groundwaters in a deep aquifer: example of the Valréas Miocene aquifer (southeastern France). Comptes Rendus de l'Academie de Sciences - Serie IIa: Earth Planet. Sci. 333, 163-170. doi:10.1016/S12518050(01)01605-6.

IAEA/WMO, 2006. Global network of isotopes in precipitation. The GNIP database. $<$ http://isohis.iaea.org>.

Ingerson, E., Pearson, F.J., 1964. Estimation of age and rate of motion of groundwater by ${ }^{14} \mathrm{C}$-method. In: Miyake, Y., Koyama, T. (Eds.), Recent Researches in Field of Hydrosphere, Atmosphere and Nuclear Geochemistry. Maruzen, Tokyo, pp. 263-283.

Jiráková, H., Huneau, F., Celle-Jeanton, H., Hrkal, Z., Le Coustumer, P., 2009. Palaeorecharge conditions of the deep aquifers of the Northern Aquitaine region (France). J. Hydrol. 368, 1-16. doi:10.1016/j.jhydrol.2009.01.017.
Kloppmann, W., Dever, L., Edmunds, W.M., 1998. Residence time of chalk groundwaters in the Paris Basin and the North German Basin: a geochemical approach. Appl. Geochem. 13, 593-606.

Lloyd, J.W., Pim, R.H., 1990. The hydrogeology and groundwater resources development of the Cambro-Ordovician sandstone aquifer in Saudi Arabia and Jordan. J. Hydrol. 121, 1-20.

Maïaux, C., 2006. Aquifères de Lorraine. In: Roux, J.C. (Ed.), Aquifères et Eaux souterraines en France, Tome 1. Editions BRGM, Orléans, pp. 299-308.

Marty, B., Dewonck, S., France-Lanord, C., 2003. Geochemical evidence for efficient aquifer isolation over geological timeframes. Nature 425, 55-58.

Merlot, S., Jusserand, C., Olive, P., Zuppi, G.M. 1996. $\mathrm{pCO}_{2}$ et minéralisation du carbone dans la zone non saturée du site des eaux minérales de Thonon-lesbains. In: Paper Presented at XXI Journées du GFHN, Groupe Fr. d'Humidimétrie, et Transferts en Milieux Poreux, Avignon, France.

Mook, W.G., 1980. Carbon-14 in hydrogeological studies. In: Fritz, P., Fontes, J.C. (Eds.), Handbook of Environmental Isotopes Geochemistry, vol. 1. Elsevier, Amsterdam, pp. 50-74.

Nastiv, M., Morin, R., Godin, R., Rouleau, A., 2008. Developing conceptual hydrogeological model for Potsdam sandstones in southwestern Quebec Canada. Hydrogeol. J. 16, 373-388.

Parkhurst, D.L., Appelo, C.A.J., 1999. User's guide to PHREEQC (version 2). A computer program for speciation, batch-reaction, one dimensional transport, and inverse geochemical calculations. US Geol. Surv. Water Resour. Invest. Rep. 99-4259.

Probst, A., Viville, D., Fritz, B., Ambroise, B., Dambrine, B., 1992. Hydrochemical budget of a small forested granitic catchment exposed to acid deposition: the Strengbach catchment case study (Vosges Massif, France). Water Air Soil Pollut. 62, 337-347.

Probst, A., Party, J.P., Fevrier, C., Dambrine, A., Thomas, A.L., Stussi, J.M., 1999. Evidence of spring water acidification in the Vosges Mountains (North-east of France). Influence of bedrock buffering capacity. Water Air Soil Pollut. 114, 395411.

Rozanski, K., 1985. Deuterium and oxygen-18 in European groundwaters. Links to atmospheric circulation in the past. Chem. Geol. 52, 349-363.

Rudolph, J., Rath, H.K., Sonntag, C., 1983. Noble gases and stable isotopes in ${ }^{14} \mathrm{C}$ dated paleowaters from central Europe and the Sahara. In: Internat. Symp. Isotope Hydrology in Water Resources Development. IAEA, Vienna, pp. 467477.

Rudolph, J., Blavoux, B., Dray, M., Olive, P., 1984. Utilisation des gaz rares pour la détermination des conditions climatiques lors de la recharge des nappes aquifères profondes. Cas des grès triasiques de Lorraine. In: Proc. 10th Réunion annuelle des sciences de la terre, Bordeaux, Soc. Geol. Fr. Edit. Paris, 490.

Salado, J., Passavy, J., 1980. Nappes des Grès du Trias Inférieur, Etude de la salinité des eaux dans le département de la Moselle. Rapport Service Régional de l'Aménagement des Eaux de Lorraine, Ministère de l'Agriculture.

Salem, O., Visser, J.H., Dray, M., Gonfiantini, R., 1980. Groundwater flow patterns in the western Lybian Arab Jamahiriaya. In: Arid-Zone Hydrology: Investigation with Isotope Techniques. IAEA, Vienna, pp. 165-179.

Shand, P., Edmunds, W.M., 2008. The baseline inorganic chemistry of European groundwaters. In: Edmunds, W.M., Shand, P. (Eds.), Natural Groundwater Quality. Blackwell Publishing Ltd., Oxford, pp. 22-58 (Chapter 2).

Smedley, P.L., Edmunds, W.M., 2002. Redox patterns and trace-element behaviour in the East Midlands Triassic sandstone aquifer. Groundwater 40, 44-58.

Surma, F., Geraud, Y., Pourcelot, L., Gauthier-Lafaye, F., Clavaud, J.B., Zamora, M., Lespinasse, M., Cathelinaud, M., 2003. Porosity microstructure of a sandstone affected by a normal fault. Bull. Soc. Géol. Fr. 3, 295-303.

Tamers, M.A., 1975. Validity of radiocarbon dates on groundwater. Geophys. Surv. 2 , 217-239.

Tournier, B., Liewig, N., Edel, J.B., Montogny, R., 1999. Accordance between the K-Ar ages of authigenetic illites and the ages of magnetic overprinting, the case of Triassic sandstones in Alsace (eastern France). Compt. Rend. Acad. Sci. - Series IIA - Earth Planet. Sci 329, 7-13.

Vaute, L., 2004. Scénarios d'exploitation de la nappe des grès du Trias inférieur dans le département de la Moselle. Rapport BRGM/RP-52822-FR. 